Article

\title{
New Insights on the Impact of Cattle Handling on Post-Mortem Myofibrillar Muscle Proteome and Meat Tenderization
}

\author{
Verónica Sierra $^{1,2}$, Laura González-Blanco ${ }^{1,2}$, Yolanda Diñeiro ${ }^{1,2}{ }^{\mathbb{D}}$, Fernando Díaz ${ }^{1}$, \\ María Josefa García-Espina ${ }^{1}$, Ana Coto-Montes ${ }^{2,3}{ }^{\mathbb{D}}$, Mohammed Gagaoua ${ }^{4, *}$ (D) and Mamen Oliván ${ }^{1,2, * \mathbb{D}}$ \\ 1 Área de Sistemas de Producción Animal, Servicio Regional de Investigación y Desarrollo \\ Agroalimentario (SERIDA), Ctra. AS-267, PK 19, 33300 Villaviciosa, Spain; veroniss@serida.org (V.S.); \\ lgblanco@serida.org (L.G.-B.); ydineiro@serida.org (Y.D.); ferdm89@gmail.com (F.D.); \\ mjgarcia@serida.org (M.J.G.-E.) \\ 2 Instituto de Investigación Sanitaria del Principado de Asturias (ISPA), Av. del Hospital Universitario, s/n, \\ 33011 Oviedo, Spain; acoto@uniovi.es \\ 3 Department of Morphology and Cell Biology, Faculty of Medicine, University of Oviedo, \\ Av. Julián Clavería, 6, 33006 Oviedo, Spain \\ 4 Food Quality and Sensory Science Department, Teagasc Food Research Centre, Dublin 15, \\ D15 KN3K Ashtown, Ireland \\ * Correspondence: Mohammed.Gagaoua@teagasc.ie or gmber2001@yahoo.fr (M.G.); \\ mcolivan@serida.org (M.O.)
}

check for updates

Citation: Sierra, V.; González-Blanco, L.; Diñeiro, Y.; Díaz, F.; García-Espina, M.J.; Coto-Montes, A.; Gagaoua, M.; Oliván, M. New Insights on the Impact of Cattle Handling on Post-Mortem Myofibrillar Muscle Proteome and Meat Tenderization. Foods 2021, 10, 3115. https://doi.org/ $10.3390 /$ foods 10123115

Academic Editor: Thierry Astruc

Received: 16 November 2021

Accepted: 13 December 2021

Published: 15 December 202

Publisher's Note: MDPI stays neutral with regard to jurisdictional claims in published maps and institutional affiliations.

Copyright: (c) 2021 by the authors. Licensee MDPI, Basel, Switzerland. This article is an open access article distributed under the terms and conditions of the Creative Commons Attribution (CC BY) license (https:// creativecommons.org/licenses/by/ $4.0 /)$

\begin{abstract}
This study investigated the effect of different cattle management strategies at farm (Intensive vs. Extensive) and during transport and lairage (mixing vs. non-mixing with unfamiliar animals) on the myofibrillar subproteome of Longissimus thoracis et lumborum (LTL) muscle of "Asturiana de los Valles" yearling bulls. It further aimed to study the relationships with beef quality traits including $\mathrm{pH}$, color, and tenderness evaluated by Warner-Bratzler shear force (WBSF). Thus, comparative proteomics of the myofibrillar fraction along meat maturation (from $2 \mathrm{~h}$ to 14 days post-mortem) and different quality traits were analyzed. A total of 23 protein fragments corresponding to 21 unique proteins showed significant differences among the treatments $(p<0.05)$ due to any of the factors considered (Farm, Transport and Lairage, and post-mortem time ageing). The proteins belong to several biological pathways including three structural proteins (MYBPC2, TNNT3, and MYL1) and one metabolic enzyme (ALDOA) that were affected by both Farm and Transport/Lairage factors. ACTA1, LDB3, and FHL2 were affected by Farm factors, while TNNI2 and MYLPF (structural proteins), PKM (metabolic enzyme), and HSPB1 (small Heat shock protein) were affected by Transport/Lairage factors. Several correlations were found between the changing proteins (PKM, ALDOA, TNNI2, TNNT3, ACTA1, MYL1, and CRYAB) and color and tenderness beef quality traits, indicating their importance in the determination of meat quality and their possible use as putative biomarkers.
\end{abstract}

Keywords: intensive management; extensive management; mixing unfamiliar animals; myofibrillar proteins; pre-slaughter stress; protein biomarkers

\section{Introduction}

Improving beef production and meat quality to cope with meet consumer demands is a major concern of the livestock production sector. It is well known that cattle intrinsic factors, such as breed and genetics, have a decisive influence on beef production and on the ultimate meat quality, therefore, different breeding strategies and meat maturation procedures must be adapted to the genetic diversity of the animals [1,2]. In this sense, there is great interest in promoting the development of native cattle breeds, as they seem to be more adapted to regional production systems and for promoting proximity trade as a sustainability strategy [3]. Apart from the intrinsic factors, there are also extrinsic factors, overall, from farm-to-fork, related to the routine handling of animals and animal-human interactions that must be considered to ensure beef quality [4]. Among them, production 
system and feeding strategies play an important role, not only due to the effect that dietary components may exert on the animal's growth rate, and muscle/meat characteristics [2,5,6], but also due to their influence on the animal's physiology, social behavior, and reactivity to stress [7-10]. Moreover, psychological, and physiological status of the animals can affect final meat quality [10]. In fact, cattle are herd animals that establish social orders, so the regrouping of animals or mixing with unfamiliar animals during transport and lairage, despite being a common husbandry practice, can have a detrimental effect on animal welfare, increasing animal stress [11,12].

On the other hand, animal handling may affect animal's emotional state, hence inducing pre-slaughter stress (PSS), whose influence on the post-mortem process of muscle-to-meat conversion has been shown in pigs $[13,14]$ and in cattle $[3,9,10,15-18]$. Those biochemical changes were evidenced using several high-throughput OMICs methods, including proteomics that revealed, for instance, that the meat tenderizing process involves myriad pathways, such as the degradation of structural proteins, energy metabolism pathways, response to stress, apoptosis, autophagy, and signaling pathways $[19,20]$ as confirmed recently by the integromics meta-analysis study of Gagaoua et al. [21]. Comparative proteomics appeared to be a useful tool to study the biological pathways underpinning the effect of PSS on the ultimate meat quality. In this context, proteomic approaches point out the possible identification of putative biomarkers from the sarcoplasmic subproteome fraction of the post-mortem muscle $[9,17,21,22]$. Since tenderness and color are considered as important beef quality traits for consumers., the impact of PSS on these attributes is worthy of investigation. Indeed, PSS is proven to have a detrimental effect due to the changes that induces in the enzymatic processes that, for example, induce the breakdown of myofibrillar structure mainly composed of structural and contractile proteins [23-26].

Based on the above, this study aimed to apply a proteomics approach to investigate the effect of pre-slaughter factors such as mixing unfamiliar animals during the transport and lairage period on the myofibrillar subproteome of young "Asturiana de los Valles" bulls reared under two divergent rearing practices (intensive or extensive management systems). This trial further provides an opportunity to identify putative protein biomarkers [27] related to beef tenderization and PSS.

\section{Materials and Methods}

\subsection{Animals and Experimental Design}

This trial used 24 yearling bulls of "Asturiana de los Valles" (AV) breed that were slaughtered between 13 and 15 months of age. AV breed is a native breed from the north of Spain, with a high growth rate and low-fat content $[28,29]$ and protected by the quality label "Ternera Asturiana", which is one of the most significant in terms of production and economic value [30]. Calves were managed with their mothers from birth to weaning, fed on concentrate and barley straw ad libitum during the winter, and assigned in spring to two different farm management systems:

(1) Intensive (" $\mathrm{I}$ ") $(n=12)$, with animals managed indoors, in pens of $6 \times 6 \mathrm{~m}$ (6 animals per pen) and finished for 100 days before slaughter with $8 \mathrm{~kg} /$ day of concentrate $(84 \%$ barley meal, $10 \%$ soya meal, $3 \%$ fat, $3 \%$ minerals, vitamins and oligoelements) and $2 \mathrm{~kg} /$ day of barley straw

(2) Extensive ("E") $(n=12)$, with animals managed outdoors in two 1.5 ha plots (6 animals per plot) and finished for 100 days before slaughter grazing on ryegrass and clover pasture $+3.5 \mathrm{~kg}$ /day of supplementation with concentrate.

At an approximate slaughter weight of $500 \mathrm{~kg}$, the animals were transported in groups of six to a commercial abattoir located at around $40 \mathrm{~km}$ from the farm where the animals were finished. Half of them from each rearing system (I and $\mathrm{E}$ ) was mixed with unfamiliar animals from other pens/groups not belonging to the study (mixing treatment " $\mathrm{M}$ ") and the other half (non-mixing treatment "NM") was maintained in their original group for transport and lairage. Thus, there were six animals assigned to each group (I-M, I-NM, E-M, E-NM). 
The experimental procedures were in compliance with the RD 53/201, where no authorization is required for practices carried out for recognized zootechnical purposes (Art 2.5d) and those that do not cause more pain than the introduction of a needle (Art 2.5f).

The pre-slaughter management lasted $6 \mathrm{~h}$ from when the animals left the farm, including the process of loading, travelling, unloading, and lairage, and was in accordance with the Council Regulation (EU) Nr. 1/2005, which relates to protecting the welfare of animals during transport and related operations. Animals were stunned with a captive bolt, slaughtered by immediate exsanguination, and dressed according to the current EU regulations (Council Regulation (EC) No 1099/2009) in accredited abattoirs.

\subsection{Muscle Sampling and Meat Quality Measurements}

The carcasses were chilled at $3{ }^{\circ} \mathrm{C}$ within $2 \mathrm{~h}$ after slaughter. Longissimus thoracis et lumborum (LTL) muscle samples (20 g) were taken from the left-side carcass of each animal at the thirteenth rib level at $2 \mathrm{~h}, 8 \mathrm{~h}$, and $24 \mathrm{~h}$ post-mortem. The muscle samples were immediately snap frozen in liquid nitrogen and stored at $-80{ }^{\circ} \mathrm{C}$ until analysis.

At $24 \mathrm{~h}$ post-slaughter, the LTL muscle was removed from the left half carcass between the sixth and the tenth ribs, and transported to the laboratory. The LTL temperature and $\mathrm{pH}$ were recorded ( $\mathrm{pH} 24)$ at the sixth rib using a digital portable $\mathrm{pH}$ meter equipped with a penetration electrode coupled with a temperature probe (InLab Solids Go-ISM, Mettler-Toledo S.A.E., Barcelona, Spain).

Meat color was recorded at $24 \mathrm{~h}$ post-mortem on three $10 \mathrm{~mm}$ diameter spots on the exposed cut surface of the LTL muscle at the seventh rib level after 60 min blooming. The coordinates lightness $\left(L^{*}\right)$, redness $\left(a^{*}\right)$, and yellowness $\left(b^{*}\right)$ were obtained using a Minolta CM-2300d portable Spectrophotometer, with an illuminant $C$ and D65 illuminant, $10^{\circ}$ standard observer angle geometry and $8 \mathrm{~mm}$ aperture size in the CIE space (Konica Minolta Inc., Osaka, Japan), and the average value of the three spots was calculated. Further, both Chroma $\left(C^{*}\right)$ and Hue angle $\left(h^{*}\right)$ were calculated according to the next equations: $C^{*}=\sqrt{ }\left(a^{* 2}+b^{* 2}\right)$ and $h^{*}=\tan ^{-1} b^{*} / a^{*}[31]$.

The rest of the LTL striploin was sliced into $3.5 \mathrm{~cm}$ steaks that were vacuum packed in polyamide $20 \mu \mathrm{m}$ / polyethylene $70 \mu \mathrm{m}$ bags and aged in darkness under refrigerated conditions $\left(4^{\circ} \mathrm{C} \pm 1{ }^{\circ} \mathrm{C}\right)$ at different post-mortem ageing times $(3,7$, and 14 days). After the corresponding ageing period, steaks for comparative proteomics were frozen at $-80{ }^{\circ} \mathrm{C}$, while the steaks for meat toughness analysis were frozen and stored at $-20^{\circ} \mathrm{C}$ for subsequent analysis. Meat toughness was measured by the Warner-Bratzler (WB) shear test on meat cooked at $75{ }^{\circ} \mathrm{C}$ from $30 \mathrm{~min}$ by immersion in a water bath. After cooling, eight cores $\left(1 \mathrm{~cm}^{2}\right.$ in cross-section) from each steak were subjected to a perpendicular cut by the WB blade set HDP/WBV with a "V" slot using the TA.XT Plus instrument (Stable Micro Systems, London, UK). The maximum load (kg) required for total split was recorded, the results were subjected to detection of outliers by box plot and the extreme values were deleted. Results were expressed as the mean WB shear force maximum load for each steak. Tenderization rate (TR, \%) was calculated as the percentage of decrease in WB shear force in a given period of time ( 3 to 7 days, 7 to 14 days, 3 to 14 days).

\subsection{Myofibrillar Protein Extraction}

Proteomic analysis was performed on the muscle samples of the 24 animals. From each animal, muscle myofibrillar extracts were obtained at 2 h, 8 h, 24 h, 3 days, 7 days, and 14 days post-mortem, following the method described by Bjarnadottir et al. [32]. Briefly, $0.5 \mathrm{~g}$ muscle samples were homogenized in $4 \mathrm{~mL}$ of Tris-EDTA-Sucrose (TES) buffer containing $10 \mathrm{mM}$ Tris [pH 7.6], $1 \mathrm{mM}$ EDTA [pH 8.0], 0.25 M sucrose, and 0.6\% protease inhibitor cocktail [P8340, Sigma-Aldrich Co., St. Louis, MO, USA], using a Polytron PT1200 E (Kinematica Inc., Luzern, Switzerland) two times for $15 \mathrm{~s}$ at maximum speed. The homogenate was centrifuged $(20 \mathrm{~min}$ at $20,000 \times g)$ at $4^{\circ} \mathrm{C}$. The resulting pellet was homogenized into $4 \mathrm{~mL}$ of lysis buffer containing $10 \mathrm{mM}$ Tris- $\mathrm{HCl} \mathrm{pH}$ [7.6], $7 \mathrm{M}$ urea, $2 \mathrm{M}$ thiourea, $2 \%$ CHAPS, and $10 \mathrm{mM}$ DTT with the polytron $2 \times 15 \mathrm{~s}$ at maximum speed. 
Subsequently, the solution was stirred at room temperature for $1 \mathrm{~h}$ in a Multi Reax stirrer (Heidolph Instruments, Schwabach, Germany) and was centrifuged at $20,000 \times g$ for $20 \mathrm{~min}$ at $4{ }^{\circ} \mathrm{C}$. The supernatant containing the myofibrillar proteins was collected and filtered through a nylon filter $(5 \mu \mathrm{m})$, aliquoted, and stored at $-80^{\circ} \mathrm{C}$. The protein content of the extract was measured by the Bradford method [33].

\subsection{Myofibrillar Subproteome Analysis (1D SDS-PAGE) and Protein Identification}

The myofibrillar muscle extracts $(30 \mu \mathrm{g})$ were prepared for SDS-PAGE as follows. First, they were denatured using a solution containing $65.8 \mathrm{mM}$ Tris/ $\mathrm{HCl} \mathrm{pH} \mathrm{6.8,} \mathrm{21 \%} \mathrm{glycerol,}$ $5 \%$ beta-mercaptoethanol, $2 \%$ SDS, $0.026 \%$ of bromophenol blue that were subsequently) heated at $100{ }^{\circ} \mathrm{C}$ for $5 \mathrm{~min}$. Second, the denatured samples were loaded into $1 \mathrm{~mm}$ dual vertical slab gels (Mini-protean, Bio-Rad Laboratories Inc., Hercules, CA, USA) for separation using a $12 \%$ resolving gel and $4 \%$ stacking gel. Pre-stained molecular weight standards (Precision Plus Protein ${ }^{\mathrm{TM}}$ All Blue Standards, Bio-Rad Laboratories Inc., Hercules, CA, USA) were added on each gel.

Overall, three gels per sample were performed. The stained gel images were captured using the UMAX ImageScanner (Amersham Biosciences, Buckinghamshire, UK). The densitometry analysis and band quantification were carried out using Image Studio Lite 5.2.5 program (LI-COR Biosciences, Lincoln, NE, USA). To account for slight variations in protein loading, the optical density of protein bands was expressed as relative abundance (normalized volume) and expressed in arbitrary units.

Bands of interest (with significant differences among the groups) were manually excised from the gels and prepared for identification by MALDI-TOF/TOF mass spectrometry. The details of this procedure were previously described by Díaz et al. [9].

\subsection{Statistical and Bioinformatics Analyses}

Raw data were scrutinized for data entry errors and outliers by boxplot. Normality of variables was tested by a Kolmogorov-Smirnoff test. For meat quality traits $(\mathrm{pH}$, meat color and WBSF), the effect of animal management at Farm " $F$ " (I vs. E), during the Transport and Lairage "TL" (M vs. NM) and the interaction $(\mathrm{F} \times \mathrm{TL})$ were analyzed using a General Lineal model procedure (SPSSv22.0 SPSS Inc., Chicago, IL, USA). Further a repeated measure ANOVA was used to investigate the effect of Treatment (I-M, I-NM, E-M, E-NM) on WBSF measured at 3, 7, and 14 days post-mortem.

For myofibrillar bands intensities measured at different post-mortem times $(2 \mathrm{~h}, 8 \mathrm{~h}$, $24 \mathrm{~h}, 3$ days, 7 days, and 14 days), the ANOVA model included Farm (F), Transport and Lairage (TL), ageing time ( $\mathrm{t}$ ), and their interactions as fixed factors and animal as covariate.

Significant differences among post-mortem times were studied by the Tukey's post-hoc test (Games-Howell when the variances were not homogeneous) at a significant level of $p \leq 0.05$.

The relationships between meat quality traits and the myofibrillar subproteome at different post-mortem times were calculated by bivariate Pearson's correlations. Moreover, principal component analysis (PCA) was performed to study the relationships among the meat quality traits and the differential proteins along meat tenderization.

The significantly changing protein bands (differential proteins) were investigated using Metascape open-source tool to identify the main enriched Gene Ontology (GO) terms among the proteins following the procedures described by Gagaoua et al. [22,34]. The STRING database (Search Tool for Retrieval of Interacting Genes, ver. 11.0 at https: //string-db.org/, accessed on 10 October 2021) was further used to construct the ProteinProtein Interactions (PPI) relating the differential proteins according to the pathways to which they belong. Moreover, the list of the identified proteins that differ among the groups were compared to the repertoire of Gagaoua et al. [21] to identify the extent of overlap with the previously identified beef tenderness biomarkers in LTL muscle. 


\section{Results}

\subsection{Meat Quality Attributes}

The handling conditions ( $\mathrm{F}$ and TL) had no significant effect on $\mathrm{pH} 24$ that showed normal values within the range 5.43-5.52, whatever the treatments. However, animals' farm management (F) affected meat color parameters (Table 1), being $L^{*}(p<0.05) b^{*}, C^{*}$, and $h^{*}(p<0.001$,) significantly lower in meat from the extensive system, that was brownish and darker, which agrees with previous literature that describes that meat from grass-fed animals is darker than meat from grain-fed animals, and attributes these differences to diet, physical activity, or a combination of both [35-37].

Table 1. Effect of Farm (F) and Transport and Lairage (TL) and their interaction on meat color parameters.

\begin{tabular}{cccccccccc}
\hline & \multicolumn{1}{c}{ Farm Management (F) } & \multicolumn{3}{c}{ Transport and Lairage (TL) } & \multicolumn{3}{c}{ Significance } \\
\hline Quality Traits & $\mathbf{I}$ & $\mathbf{E}$ & SEM & NM & M & SEM & F & TL & F $\times$ TL \\
\hline $\mathrm{pH}$ & 5.6 & 5.46 & 0.05 & 5.49 & 5.58 & 0.05 & NS & NS & NS \\
$L^{*}$ & 41.86 & 38.20 & 0.99 & 38.73 & 41.33 & 0.99 & $*$ & NS & NS \\
$a^{*}$ & 12.03 & 10.82 & 0.523 & 10.4 & 12.45 & 0.523 & NS & $*$ & $*$ \\
$b^{*}$ & 15.49 & 10.28 & 0.522 & 12.19 & 13.58 & 0.522 & $* * *$ & NS & NS \\
$C^{*}$ & 19.64 & 14.97 & 0.681 & 16.13 & 18.49 & 0.681 & $* * *$ & $*$ \\
$h^{*}$ & 52.49 & 43.61 & 1.04 & 49.07 & 47.03 & 1.04 & $* * *$ & NS & NS \\
\hline
\end{tabular}

F: Management at farm; TL: Management during transport and lairage; NM: Non-mixing; M: Mixing; NS: not significant; ${ }^{*} p<0.05$; $* * *<0.001$; SEM: standard error of the mean.

The effect of animal mixing during transport and lairage (TL) and the F $\times$ TL interaction were significant for $a^{*}$ and $C^{*}(p<0.05)$. In both parameters, meat from mixed animals had higher values compared to the meat from non-mixed animals, being $a^{*}(12.45$ vs. 10.4$)$ and $C^{*}(18.49$ vs. 16.13$)$ for $\mathrm{M}$ and $\mathrm{NM}$, respectively.

Farm rearing system were found to significantly affect meat toughness $(p<0.001)$ at 14 days post-mortem when meat from the intensive treatment showed lower values. These findings are in agreement to those of previous studies that found a negative effect of extensive treatment on tenderness [38,39].

When comparing the evolution of meat toughness in the different handling treatments (I-M, I-NM, E-M and E-NM) (Figure 1A), no significant differences were found at 3 days postmortem; however lower values of WBSF were found at $7(p<0.05)$ and 14 days $(p<0.001)$ in meat from the I-NM animals. When looking to the tenderization rate (Figure 1B), a decrease in meat toughness along ageing, it can be seen that the meat from animals of the intensive treatment had a higher tenderization rate in the global studied period ( 3 to 14 days) being higher for I-NM animals (22\%) in the earliest period from 3 to 7 days, and for I-M animals in the last period of the post-mortem ageing (22\%) from 7 to 14 days.

Overall, meat from animals of the I-M group showed redder meat and a lower tenderization rate, which could together be related to higher PSS. In fact, previous studies of the serum biomarkers of stress (cortisol, lactate, glucose, amyloid A, and haptoglobin) in this group of animals $[9,18]$ evidenced that I-M animals were the most sensitive to stress reactivity, as indicated by its high serum haptoglobin levels.

\subsection{Separation and Identification of Myofibrillar Subproteome}

1D SDS-PAGE of the myofibrillar proteins allowed the visualization of 36 protein bands (ranging from 15 to $200 \mathrm{kDa}$ ) from the muscle myofibrillar subproteome, as shown in Figure 2. 

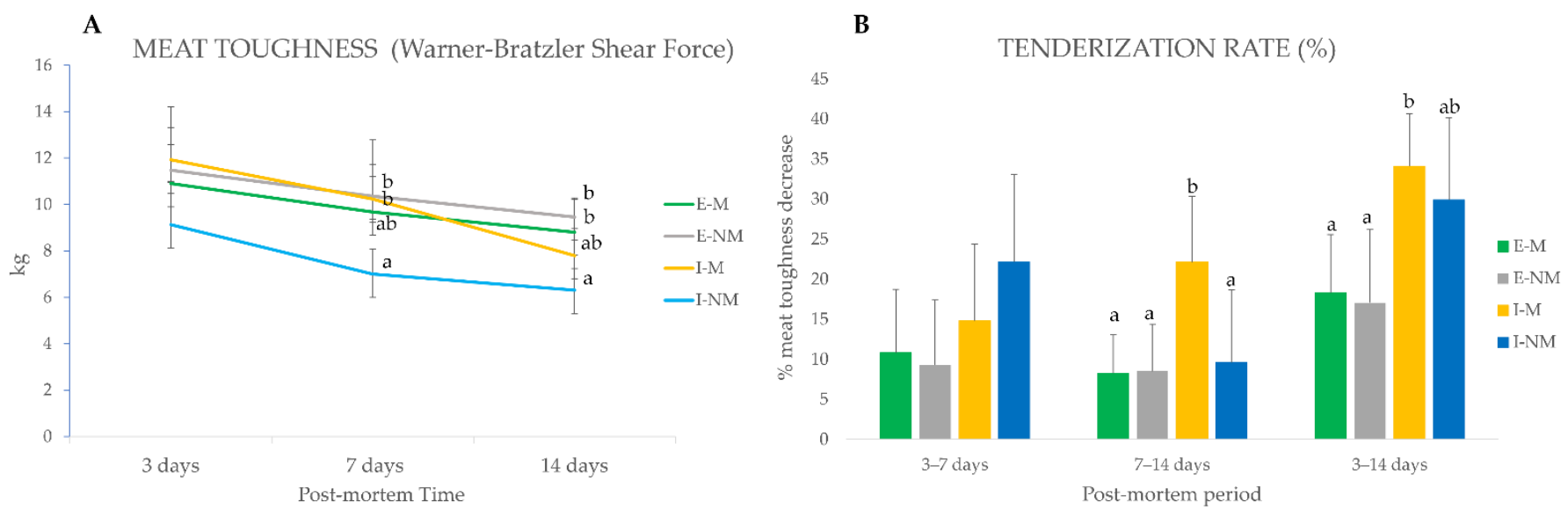

Figure 1. Post-mortem evolution of instrumental toughness for meat from the different handling treatments. (A) WarnerBraztler Shear force at 3, 7, and 14 days post-mortem. (B) Tenderization rate (\%) calculated as the percentage of decrease in toughness in a given period of time ( 3 to 7 days, 7 to 14 days, 3 to 14 days). Different letters indicate significant differences $(p<0.05)$ among treatments (I-M, I-NM, E-M and E-NM) at 3, 7 or 14 days.

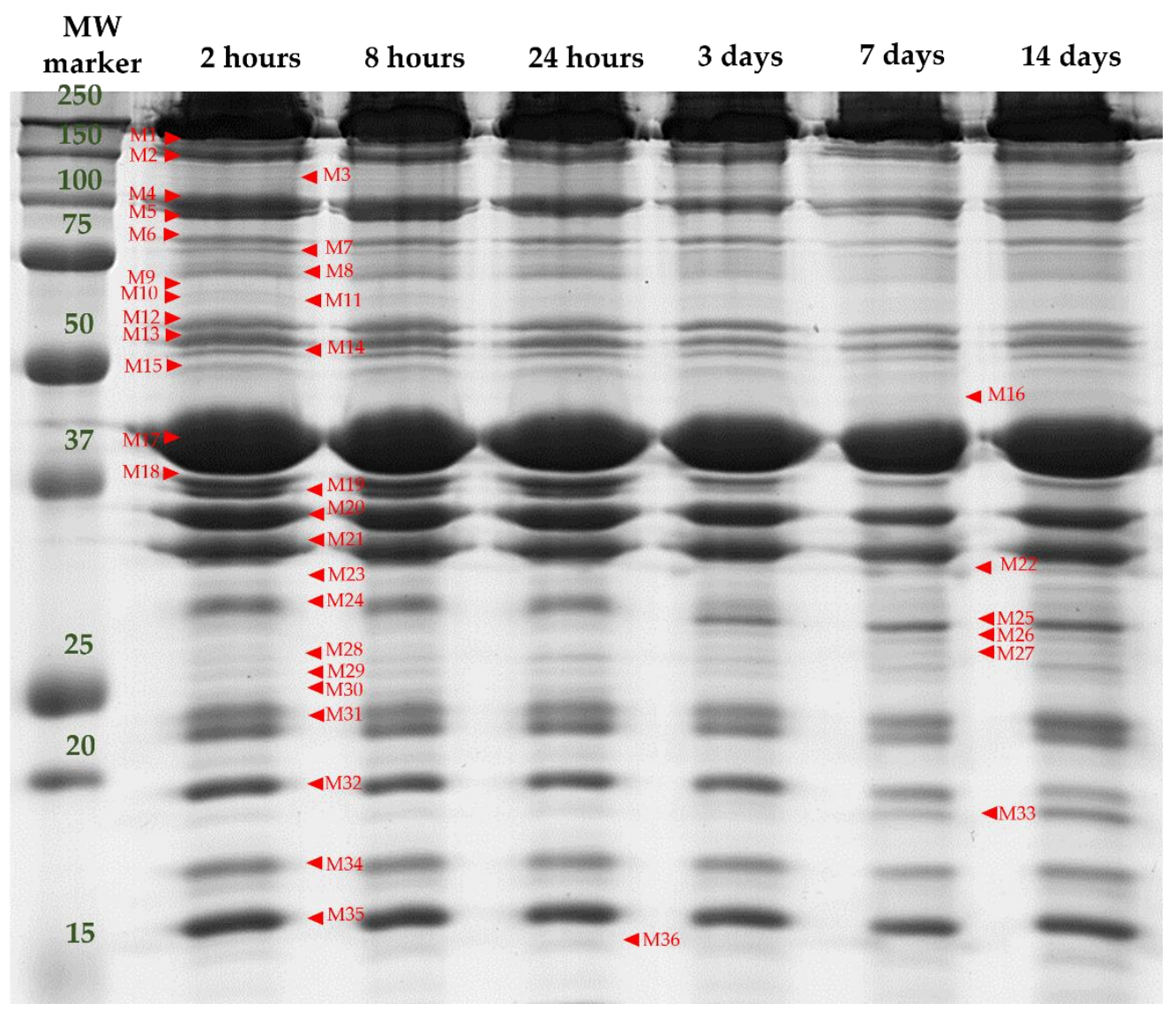

Figure 2. A representative 1D SDS-PAGE electrophoretic pattern of the myofibrillar subproteome profile of the LTL muscle of a yearling bull from "Asturiana de los Valles" at different post-mortem times ( 2 h, 8 h, 24 h, 3 days, 7 days, 14 days). MW marker: pre-stained molecular weight marker (All Blue pre-stained, Biorad). Band names are denoted by M (Myofibrillar proteins) followed by a number.

Among the 36 bands analyzed in the myofibrillar subproteome, 23 bands were significantly affected by at least one of the factors analyzed in this study (F, TL, and $t$ ), as shown in Table 2. 


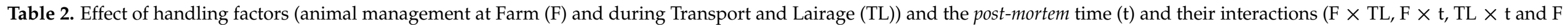
$\times \mathrm{TL} \times \mathrm{t}$ ) on the myofibrillar subproteome (arbitrary units).

\begin{tabular}{|c|c|c|c|c|c|c|c|c|c|c|c|c|c|c|c|c|c|c|c|c|}
\hline \multirow[b]{2}{*}{$\begin{array}{l}\text { Band } \\
\text { [MWe] }\end{array}$} & \multicolumn{3}{|c|}{$\begin{array}{c}\text { Farm } \\
\text { Management (F) }\end{array}$} & \multicolumn{2}{|c|}{$\begin{array}{l}\text { Transport and } \\
\text { Lairage (TL) }\end{array}$} & \multicolumn{9}{|c|}{ Post-Mortem Time (t) } & \multicolumn{6}{|c|}{ Significance } \\
\hline & I & E & SEM & NM & M & SEM & $2 \mathrm{~h}$ & $8 \mathrm{~h}$ & $24 \mathrm{~h}$ & $3 \mathrm{~d}$ & $7 \mathrm{~d}$ & $14 \mathrm{~d}$ & SEM & $\mathbf{F}$ & TL & $t$ & $\mathbf{F} \times \mathbf{T L}$ & $\mathbf{F} \times \mathbf{t}$ & $\mathbf{T L} \times \mathbf{t}$ & $\mathbf{F} \times \mathbf{T L} \times \mathbf{t}$ \\
\hline M1 (155.03) & 4.66 & 3.67 & 0.25 & 4.76 & 3.87 & 0.15 & 4.08 & 4.39 & 4.22 & 4.4 & 4.36 & 3.57 & 0.24 & * & $* *$ & NS & NS & NS & NS & NS \\
\hline M4 (99.16) & 5.94 & 4.97 & 0.29 & 5.48 & 5.43 & 0.17 & $6.04 \mathrm{~b}$ & $5.99 \mathrm{~b}$ & $5.71 \mathrm{ab}$ & $5.03 \mathrm{ab}$ & $5.03 \mathrm{ab}$ & $4.93 \mathrm{a}$ & 0.28 & NS & NS & $* *$ & NS & NS & NS & NS \\
\hline M6 (83.56) & 2.18 & 2.0 & 0.09 & 2.102 & 2.08 & 0.06 & $2.05 \mathrm{ab}$ & $2.24 \mathrm{~b}$ & $2.28 \mathrm{~b}$ & $2.13 \mathrm{~b}$ & $2.07 \mathrm{ab}$ & $1.78 \mathrm{a}$ & 0.09 & NS & NS & $* *$ & NS & NS & NS & NS \\
\hline M9 (71.02) & 1.23 & 1.36 & 0.06 & 1.27 & 1.32 & 0.04 & $1.37 \mathrm{~b}$ & $1.43 \mathrm{~b}$ & $1.33 \mathrm{~b}$ & $1.37 \mathrm{~b}$ & $1.21 \mathrm{a}$ & $1.05 \mathrm{a}$ & 0.06 & NS & NS & $* * *$ & NS & NS & NS & NS \\
\hline M12 (59.93) & 2.63 & 2.22 & 0.15 & 2.63 & 2.22 & 0.09 & 2.35 & 2.53 & 2.61 & 2.60 & 2.35 & 2.12 & 0.15 & NS & $* *$ & NS & $* * *$ & NS & NS & NS \\
\hline M13 (56.24) & 2.42 & 2.49 & 0.09 & 2.47 & 2.44 & 0.05 & $2.47 \mathrm{ab}$ & $2.70 \mathrm{~b}$ & $2.59 \mathrm{~b}$ & $2.37 \mathrm{ab}$ & $2.37 \mathrm{ab}$ & $2.25 \mathrm{a}$ & 0.09 & NS & NS & $* *$ & NS & NS & NS & NS \\
\hline M15 (50.74) & 1.5 & 1.57 & 0.06 & 1.49 & 1.58 & 0.04 & $1.47 \mathrm{ab}$ & $1.62 \mathrm{~b}$ & $1.62 \mathrm{~b}$ & $1.64 \mathrm{~b}$ & $1.52 \mathrm{ab}$ & $1.34 \mathrm{a}$ & 0.06 & NS & NS & $* *$ & * & NS & NS & NS \\
\hline M17 (40.53) & 16.14 & 19.3 & 0.79 & 17.64 & 17.8 & 0.47 & $19.19 \mathrm{ab}$ & $16.23 \mathrm{a}$ & $17.08 \mathrm{a}$ & 16.93 a & $16.91 \mathrm{a}$ & $19.98 \mathrm{~b}$ & 0.76 & $*$ & NS & $* *$ & NS & NS & NS & NS \\
\hline M18 (37.64) & 2.96 & 2.98 & 0.12 & 2.96 & 2.98 & 0.07 & $3.27 \mathrm{bc}$ & $3.49 \mathrm{c}$ & $3.38 \mathrm{c}$ & $2.82 \mathrm{ab}$ & $2.52 \mathrm{a}$ & $2.34 \mathrm{a}$ & 0.12 & NS & NS & $* * *$ & NS & NS & NS & NS \\
\hline M19 (36.88) & 2.34 & 1.94 & 0.07 & 2.24 & 2.05 & 0.04 & $2.61 \mathrm{c}$ & $2.73 \mathrm{c}$ & $2.67 \mathrm{c}$ & $1.99 \mathrm{~b}$ & $1.49 \mathrm{a}$ & $1.38 \mathrm{a}$ & 0.07 & $* *$ & $* *$ & $* * *$ & NS & $* *$ & NS & NS \\
\hline M20 (35.03) & 7.47 & 7.04 & 0.22 & 7.28 & 7.23 & 0.13 & $7.09 \mathrm{abc}$ & $7.58 \mathrm{bc}$ & $8.02 \mathrm{c}$ & $7.68 \mathrm{~b}$ & $6.84 \mathrm{ab}$ & $6.33 a$ & 0.21 & NS & NS & $* * *$ & NS & NS & NS & NS \\
\hline M21 (32.95) & 6.1 & 5.9 & 0.17 & 6.01 & 5.99 & 0.1 & $5.26 \mathrm{a}$ & $5.7 \mathrm{ab}$ & $5.74 \mathrm{ab}$ & $6.56 \mathrm{c}$ & $6.62 \mathrm{c}$ & $6.1 \mathrm{c}$ & 0.16 & NS & NS & $* * *$ & NS & NS & NS & NS \\
\hline M23 (30.89) & 1.03 & 1.25 & 0.05 & 1.15 & 1.13 & 0.03 & $1.05 \mathrm{a}$ & $1.04 \mathrm{a}$ & $1.04 \mathrm{a}$ & $1.06 \mathrm{a}$ & $1.21 \mathrm{ab}$ & $1.44 \mathrm{~b}$ & 0.05 & $*$ & NS & $* * *$ & NS & NS & NS & NS \\
\hline M24 (29.75) & 2.4 & 2.6 & 0.1 & 2.49 & 2.51 & 0.06 & $3.04 \mathrm{~d}$ & $2.89 \mathrm{~d}$ & $2.74 \mathrm{~cd}$ & $2.32 \mathrm{bc}$ & $2.17 \mathrm{ab}$ & $1.84 \mathrm{a}$ & 0.10 & NS & NS & $* * *$ & $* * *$ & NS & NS & NS \\
\hline M25 (28.67) & 1.58 & 1.71 & 0.08 & 1.61 & 1.68 & 0.05 & $0.89 \mathrm{a}$ & $0.92 \mathrm{a}$ & $0.97 \mathrm{a}$ & $1.68 \mathrm{~b}$ & $2.51 \mathrm{c}$ & $2.89 \mathrm{~d}$ & 0.08 & NS & NS & $* * *$ & NS & $*$ & NS & NS \\
\hline M26 (27.82) & 0.65 & 0.8 & 0.03 & 0.71 & 0.73 & 0.02 & $0.54 \mathrm{a}$ & $0.53 \mathrm{a}$ & $0.51 \mathrm{a}$ & $0.73 \mathrm{~b}$ & $0.95 \mathrm{c}$ & $1.08 \mathrm{c}$ & 0.03 & $*$ & NS & $* * *$ & $*$ & * & NS & NS \\
\hline M27 (27.25) & 0.56 & 0.69 & 0.02 & 0.6 & 0.65 & 0.01 & $0.47 \mathrm{a}$ & $0.45 \mathrm{a}$ & $0.45 \mathrm{a}$ & $0.62 \mathrm{~b}$ & $0.83 \mathrm{c}$ & $0.93 \mathrm{~d}$ & 0.02 & $* *$ & $*$ & $* * *$ & NS & NS & NS & NS \\
\hline M30 (25.10) & 1.22 & 1.33 & 0.06 & 1.35 & 1.2 & 0.04 & $1.33 \mathrm{bc}$ & $1.37 \mathrm{bc}$ & $1.42 \mathrm{c}$ & $1.24 \mathrm{abc}$ & $1.16 \mathrm{ab}$ & $1.11 \mathrm{a}$ & 0.06 & NS & $* *$ & $* *$ & $* * *$ & NS & NS & NS \\
\hline M31 (23.20) & 5.53 & 6.04 & 0.13 & 5.61 & 5.96 & 0.08 & 5.81 & 5.77 & 5.59 & 5.69 & 5.86 & 5.97 & 0.12 & $*$ & $* *$ & NS & NS & NS & NS & NS \\
\hline M32 (19.89) & 3.83 & 3.7 & 0.13 & 3.66 & 3.86 & 0.07 & $4.11 \mathrm{bc}$ & $4.09 \mathrm{bc}$ & $3.98 \mathrm{bc}$ & $4.23 \mathrm{c}$ & $3.64 \mathrm{~b}$ & $2.52 \mathrm{a}$ & 0.12 & NS & $* *$ & $* * *$ & NS & $* * *$ & NS & NS \\
\hline M33 (19.07) & 1.17 & 1.22 & 0.08 & 1.2 & 1.18 & 0.05 & $0.79 \mathrm{a}$ & $0.77 \mathrm{a}$ & $0.79 \mathrm{a}$ & $1.05 \mathrm{a}$ & $1.54 \mathrm{~b}$ & $2.21 \mathrm{c}$ & 0.08 & NS & NS & $* * *$ & NS & $* * *$ & NS & NS \\
\hline M34 (17.54) & 3.84 & 3.92 & 0.11 & 3.96 & 3.8 & 0.07 & 3.82 & 3.81 & 3.78 & 3.86 & 3.94 & 4.06 & 0.13 & NS & NS & NS & * & NS & NS & NS \\
\hline M35 (16.05) & 5.76 & 5.37 & 0.14 & 5.43 & 5.7 & 0.08 & 5.45 & 5.49 & 5.34 & 5.62 & 5.73 & 5.76 & 0.05 & NS & $*$ & NS & NS & NS & NS & NS \\
\hline
\end{tabular}

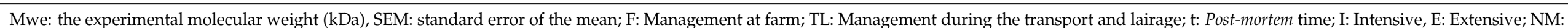

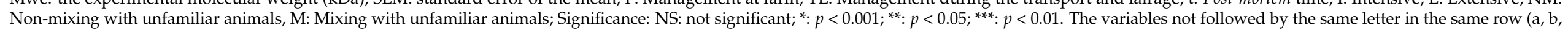
$c$, and d) are statistically different $(p<0.05)$. 
It is important to note that these band intensity differences are due to the effect that handling factors may have in either the synthesis of a determined protein and/or to variations in the muscle post-mortem metabolism, which may result in increased proteolysis of that protein decreasing its relative abundance or causing its disappearance and the consequent increases of smaller protein fragments/peptides. Therefore, the relative abundance of a given (intact) protein is a balance between synthesis and degradation [22].

Table 3 shows the identification of protein bands with significant intensity differences among treatments. These proteins belong to three major biological pathways (Figure 3A):

$>$ Muscle contraction, structure and associated proteins: M1 (Myosin-binding protein C, fast-type isoform X2 "MYBPC2"), M4 (Alpha-actinin-3 “ACTN3"), M13 (Desmin, partial "DES"), M17 (Actin, alpha skeletal muscle "ACTA1"), M21 (Tropomyosin alpha-1 chain "TPM1"), M23 (LIM domain-binding protein 3 isoform X5 "LDB3"), M24 (Four and a half LIM domains protein 1 isoform 1 "FHL1"), M25 and M27 (Troponin T, fast skeletal muscle isoform X31 "TNNT3"), M26 (Four and a half LIM domains protein 1 isoform 2 "FHL2"), M31 (Myosin light chain 1/3 skeletal muscle isoform "MYL1"), M32 (Troponin I, fast skeletal muscle "TNNI2"), M34 (Troponin C, skeletal muscle "TNNC1" and M35 (Myosin regulatory light chain 2, skeletal muscle isoform "MYLPF");

$>$ Energy metabolism and associated pathways: M6 (ATP-dependent 6-phosphofructokinase, muscle type "PFKM"), M12 (Pyruvate kinase PKM isoform X1 "PKM"), M15 (ATP synthase subunit beta, mitochondrial precursor “ATP5F1B"), M18 y M19 (Fructosebiphosphate aldolase A "ALDOA") and M20 (Glyceraldehide-3-phosphate dehydrogenase, "GAPDH");

> Heat shock proteins: M9 (Heat Shock 70 kDa protein 1A "HSPA1A"), M30 (Heat Shock protein family B member 1 variant 1 "HSPB1") and M33 (Alpha-crystallin B chain "CRYAB").

Table 3. Protein identification of myofibrillar bands separated by 1D-SDS-PAGE that showed significant differences with treatments (Farm, Transport and Lairage, and/or post-mortem time).

\begin{tabular}{|c|c|c|c|c|c|c|}
\hline $\begin{array}{c}\text { Band: Gene } \\
\text { Name }\end{array}$ & Identification & $\begin{array}{c}\text { Accession } \\
\text { Number }\end{array}$ & $\begin{array}{c}\text { MOWSE } \\
\text { Scores }\end{array}$ & $\begin{array}{c}\text { Sequence } \\
\text { Coverage } \\
(\%)\end{array}$ & $\begin{array}{c}\text { Matched } \\
\text { Queries }\end{array}$ & MWt \\
\hline M1: MYBPC2 & Myosin-binding protein $C$, fast-type isoform $\mathrm{X} 2$ & E1BNV1 & 295 & 24 & 25 & 128.5 \\
\hline M4: ACTN3 & Alpha-actinin-3 & Q0III9 & 506 & 38 & 35 & 103.7 \\
\hline M6: PFKM & ATP-dependent 6-phosphofructokinase, muscle type & Q0IIG5 & 352 & 40 & 42 & 86.1 \\
\hline M9: HSPA1A & Heat Shock $70 \mathrm{kDa}$ protein $1 \mathrm{~A}$ & Q27975 & 288 & 38 & 24 & 70.5 \\
\hline M12: PKM & Pyruvate kinase PKM, isoform X1 & A5D984 & 822 & 66 & 46 & 58.5 \\
\hline M13: DES & Desmin, partial & O62654 & 246 & 54 & 21 & 52.6 \\
\hline M15: ATP5F1B & ATP synthase subunit beta, mitochondrial precursor & P00829 & 445 & 48 & 25 & 56.2 \\
\hline M17: ACTA1 & Actin, alpha skeletal muscle & P68138 & 522 & 52 & 24 & 42.4 \\
\hline M18: ALDOA & Fructose-biphosphate aldolase A & A6QLL8 & 430 & 62 & 24 & 39.9 \\
\hline M19: ALDOA & Fructose-biphosphate aldolase A & A6QLL8 & 286 & 60 & 21 & 39.9 \\
\hline M20: GAPDH & Glyceraldehide-3-phosphate dehydrogenase & P10096 & 394 & 45 & 20 & 36.1 \\
\hline M21: TPM1 & Tropomyosin alpha-1 chain & Q5KR49 & 199 & 41 & 15 & 32.7 \\
\hline M23: LDB3 & LIM domain-binding protein 3 isoform $\times 5$ & G3N3C9 & 180 & 55 & 19 & 30.9 \\
\hline M24: FHL1 & Four and a half LIM domains protein 1 isoform 1 & G3MZ95 & 671 & 87 & 34 & 35.5 \\
\hline M25: TNNT3 & Troponin T, fast skeletal muscle isoform X31 & Q8MKI3 & 206 & 45 & 18 & 28.9 \\
\hline M26: FHL2 & Four and a half LIM domains protein 1 isoform 2 & Q2KI95 & 95 & 37 & 11 & 33.8 \\
\hline M27: TNNT3 & Troponin T, fast skeletal muscle isoform X31 & Q8MKI3 & 178 & 43 & 15 & 28.9 \\
\hline M30: HSPB1 & Heat Shock protein family B member 1 variant 1 & Q3T149 & 368 & 73 & 14 & 22.4 \\
\hline M31: MYL1 & Myosin light chain $1 / 3$ skeletal muscle isoform & A0JNJ5 & 425 & 77 & 18 & 21.1 \\
\hline M32: TNNI2 & Troponin I, fast skeletal muscle & F6QIC1 & 194 & 70 & 23 & 21.6 \\
\hline M33: CRYAB & Alpha-crystallin B chain & P02510 & 163 & 69 & 13 & 20.1 \\
\hline M34: TNNC1 & Troponin C, skeletal muscle & P63315 & 333 & 56 & 15 & 18.3 \\
\hline M35: MYLPF & Myosin regulatory light chain 2 , skeletal muscle isoform & Q0P571 & 517 & 66 & 21 & 19.11 \\
\hline
\end{tabular}

The MOWSE score: numeric descriptor of the likelihood that the identification is correct. Protein scores greater than 94 are significant $(p<0.05)$; Mwt: theoretical molecular weight $(\mathrm{kDa})$. 

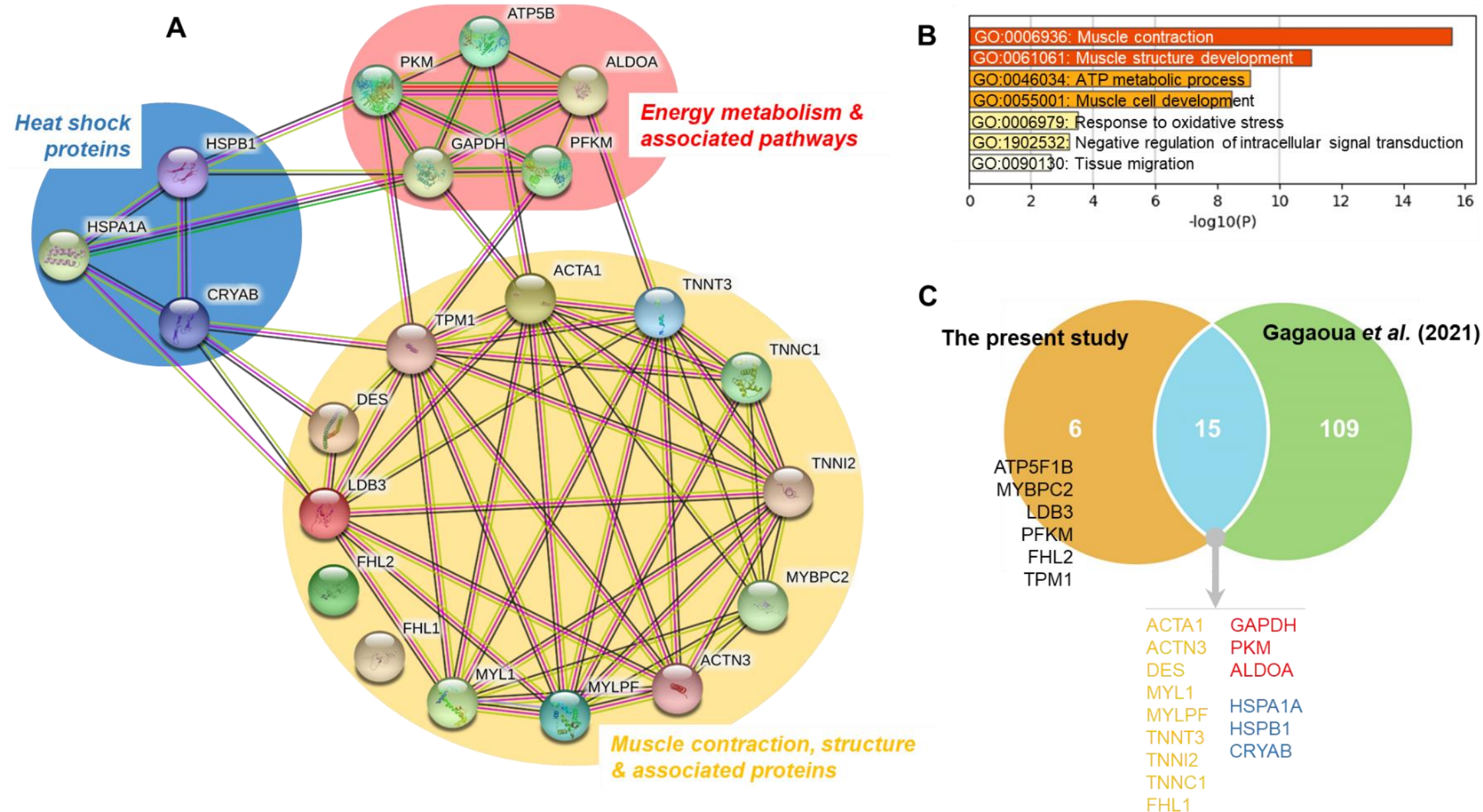

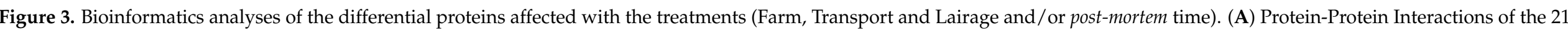

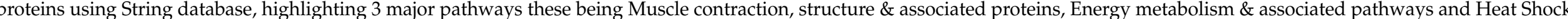

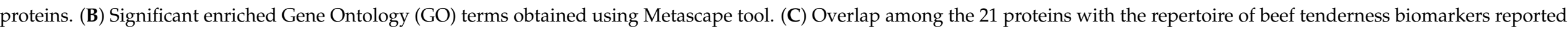
in the database of Gagaoua et al. [18]. The 15 common proteins were highlighted by the corresponding molecular pathway color as in (A). 
It is important to note that some proteins appeared in more than one band, as was the case of ALDOA (M18 and M19) and TNNT3 (M25 and M27), probably due to differences in the molecular weight or to conformational changes of the different proteolytic fragments originated from the same protein. The analyses of these differential proteins, which finally constitute 21 unique proteins (Table 3 and Figure 3A), allowed for the construction of an interconnected network (Figure 3A), highlighting the importance of muscle contraction and structure pathways. The Gene Ontology (GO) analysis allowed for the identification of seven enriched GO terms (Figure 3B), from which the top two enriched terms being GO:0006936: Muscle contraction and GO:0061061: Muscle structure development. These were followed by GO:0046034: ATP metabolic process, GO:0055001: Muscle cell development, GO:0006979: Response to oxidative stress, GO:1902532: Negative regulation of intracellular signal transduction and GO:0090130: Tissue migration.

It must be noted that most protein bands from the myofibrillar subproteome $(61 \%)$ correspond to structural insoluble proteins, but soluble proteins such as glycolytic enzymes $(26 \%)$ or HSPs $(13 \%)$ were also found in the myofibrillar fraction (Figure $3 \mathrm{~A})$. This can be due to a decrease of solubility, maybe partly as a consequence of the early $\mathrm{pH}$ drop while the muscle temperature is still high, and also to the relationships that exist among the proteins [34], as confirmed in the network of Figure 3A. In fact, such conditions may cause denaturation of proteins which became insoluble, and their aggregation and precipitation onto myofibrils $[24,40]$. In support of this, the recent study by Gagaoua et al. showed that the maturation process involves interconnected molecular pathways in a $\mathrm{pH}$-dependent manner leading, for instance, to the concomitant appearance of two major proteolytic fragments at 110 and $30 \mathrm{kDa}$, based on 1DE electrophoresis [34]. These two protein bands appearing during ageing, also observed in this study, increase in their intensity as a function of post-mortem time in a $\mathrm{pH}$ decline-dependent manner. LC-MS/MS analysis yielded 22 unique proteins for the $110 \mathrm{kDa}$ fragment and 13 for the $30 \mathrm{kDa}$, with four common proteins related to both actin and fibrinogen complex. The Gene Ontology analysis revealed that a myriad of biological pathways are influential with many of them, as confirmed in the present study (Figure 3), and were related to proteins involved primarily in muscle contraction and structure. Other pathways were apoptotic mitochondrial changes, calcium and ion transport, energy metabolism, etc. Interestingly, most of the proteins composing these two fragments among others that appear or disappear during the tenderization process and in line to the results of this study have been so far identified as biomarkers of beef tenderness (Gagaoua et al., 2021) [21]. In addition, HSPs can translocate and accumulate in the cytoskeleton and myofibrillar proteins during early post-mortem stages, as they exert a protective role against muscle degradation [40]. These facts reinforce the need to consider different cell fractions and the movements of proteins between cytoskeletal and myofibrillar structures, for an accurate and reliable study of the process of conversion of the muscle into meat, as has been highlighted by previous studies [21,41].

\subsubsection{Handling Effects on the Muscle Contraction, Structure and Associated Proteins}

Among the protein bands with structural and contraction functions, only M27 (27.25 $\mathrm{kDa}$ ), identified as Troponin T, fast skeletal muscle isoform X31 (TNNT3), was affected by the three factors analyzed in this study (F, TL, and $t$ ). Higher intensities of M27 were found in the muscle of the animals from the extensive treatment $(p<0.01)$ and mixed group animals during transport and lairage $(p<0.05)$. Further, a significant increase $(p<0.001)$ of TNNT3 band intensity with post-mortem time was found. Band M25 with a molecular weight of $28.67 \mathrm{kDa}$, was also identified as TNNT3, but it did not show significant differences with F or TL, but a significant increase with post-mortem time $(p<0.001)$. Troponin $\mathrm{T}$ is the most frequently identified differential biomarker of ongoing proteolysis and tenderization due to the appearance of degradation fragments of $30 \mathrm{kDa}$ and $28 \mathrm{kDa}$ correlated to meat tenderness [25,34,42-44]. TNNT3 is one of the proteins of the Troponin complex, composed of three regulatory proteins (Troponin T, C and I) that are integral to muscle contraction. It is well known that tenderization acts on all the proteins of the 
complex and it was identified as a robust biomarker of beef tenderness in the study of Gagaoua et al. [21], as evidenced in the Venn diagram of Figure 3C. Accordingly, our results showed changes in all the proteins of the Troponin complex. Bands M32 and M34 were identified as TNNI2 and TNNC1 respectively. TNNI2 was affected by TL, with higher intensity $(p<0.01)$ in meat from the mixed animals, and also a significant effect of postmortem time was observed with a significant decrease $(p<0.001)$ after 3 days post-mortem in meat from E-M, E-NM and I-NM treatments, but delayed for I-M, which seems to indicate slower tenderization rate.

Other bands with significant changes correspond to myosin related proteins M1 (Myosin-binding protein C, fast-type isoform X2 "MYBPC2") and M31 (Myosin light chain $1 / 3$ skeletal muscle isoform "MYL1") were affected by both F and TL but not by ageing time. MYBPC2 showed higher intensity $(p<0.05)$ in meat from the indoor reared animals and in meat from the non-mixed group $(p<0.01)$, which could be related to differences in the level of physical exercise, as found for MYOM2, a major component of the myofibrillar subproteome that appeared in the sarcoplasmic subproteome of these animals, in agreement with the recent studies of Diaz et al., [9] and Gagaoua et al. [34]. MYBPC2 belongs to the Myosin Binding Proteins family formed by sarcomeric proteins located in the A-band in close association with the thick filaments that are known as regulators of the myofilament contractility [45]. MYBPC exists in three main isoforms: skeletal slow (MYBPC1), skeletal fast (MYBPC2), and cardiac (MYBPC3). MYPBC1 and MYBPC2 were recently identified to be the major components of the $110 \mathrm{kDa}$ fragment appearing during the tenderization of beef in a pH dependent manner [34]. It is also important to note that a closely member, the myosin binding protein $\mathrm{H}(\mathrm{MYBPH})$ has been previously identified as a negative biomarker of color and beef tenderness, whatever the gender, due to its significant effect on length, thickness, and lateral alignment of myosin filaments [21,46,47]. In this work, MYBPC2 showed higher intensity levels in the I-NM meat, which was the tenderer one, hence confirming the findings by Gagaoua et al. [21,34] proposing this protein as a good marker of meat tenderization.

MYBPC has a theoretical molecular weight of approximately $130 \mathrm{kDa}$; however, the band identified as MYBPC2 in our study shows a higher experimental molecular weight $(155 \mathrm{kDa})$ what could be indicative of aggregation of this protein or to its interaction with nebulin and other proteins as observed in earlier studies [34,48]. These modifications may explain the loss of its function in the alignment of myosin filaments, and therefore the positive role it might play on tenderness. On the other hand, MYL1 is a member of the Myosin light chains that are crucial for muscle function in terms of contraction velocity and power. In this work, MYL1 band showed higher intensities in the meat reared outdoors $(p<0.05)$ and in meat from mixed animals $(p<0.01)$. Apart from MYL1, another band (M35) from the same family was identified as Myosin regulatory light chain 2, skeletal muscle isoform "MYLPF" that was not different within farm management, but was significantly affected by TL with higher values at the M treatment $(p<0.05)$ in line with the findings for MYL1. Post-mortem disruption of myosin light and heavy chains and actin in the actomyosin complex plays a central role in the muscle to meat conversion and may have a direct effect on tenderness [49]. The post-mortem concentration of these proteins has been previously associated with pork and beef tenderness [50,51], and belong to the robust list of biomarkers of beef tenderness shortlisted by Gagaoua et al. [21]. Increased proteolysis of MYL1 has also been described in dark-cutting beef $[22,26]$. It is worthy to note that myosin lights chains were also identified as biomarkers of several beef color traits [47].

Apart from the aforementioned, management at farms affected other three structural proteins: M17 (Actin, alpha skeletal muscle "ACTA1"), M23 (LIM domain-binding protein 3 isoform X5 "LDB3) and M26 (Four and a half LIM domains protein 1 isoform 2 "FHL2"). All of them were more intense $(p<0.05)$ in the meat from animals reared outdoors. Actin is the second most abundant myofibrillar protein, after myosin, and was described as the top biomarker of beef tenderness (Figure 3C) [21]. The breakdown of transverse cytoskeletal actin filaments can cause detachment of the sarcolemma from the basal lamina and the 
extracellular matrix network, causing muscle cells degradation and hence increasing tenderness; therefore, actin has been found to be a good biomarker of tenderness [21,40,49,52]. The other two proteins affected by farm management were the LIM-domain containing proteins, LDB3 and FHL2. The LIM domain is a cysteine-histidine rich, zinc-coordinating domain, consisting of two tandemly repeated zinc fingers. The LIM domain-containing proteins are known to play critical roles in vertebrate development and cellular differentiation. The LDB3 protein, located in the sarcomere, is essential for maintaining $\mathrm{Z}$ line structure and muscle integrity [53]. FHL2 is a member of the four and a half LIM domain protein family (FHL), with an important role in muscle development [54]. To the best of our knowledge, this protein has never been related to meat quality before; however another protein from the FHL family, the Four and a half LIM domains protein 1 isoform 1 (FHL1,) also known as Cypher protein, has been related to the release of $\alpha$-actinin and the weakening of the Z-disc during meat tenderization $[55,56]$. In the present study, band M24 was identified as FHL1 and, contrary to what was found for FHL2, only a significant decrease with post-mortem ageing and a significant interaction $\mathrm{F} \times \mathrm{TL}$ (E-NM $>\mathrm{E}-\mathrm{M}=\mathrm{I}-\mathrm{M}$ $>$ I-NM) was observed $(p<0.001)$. Previous studies found increased intensity of FHL1 in DFD meat $[16,22,57]$.

The other structural protein bands found in the myofibrillar extract were affected only by post-mortem time, with a significant decrease $(p<0.01)$ of M4 (Alpha-actinin-3 "ACTN3") and M13 (Desmin, partial "DES") and a significant increase $(p<0.001)$ of M21 (Tropomyosin alpha-1 chain "TPM1"). It is important to note that the post-mortem ageing time is the factor that causes the greatest differences in the intensity of the muscle contraction and structural proteins, with 10 out of the 14 structural bands showing significant differences in agreement to the very recent findings of Gagaoua et al. [34]. Most of these band's intensities remain similar at the earliest post-mortem period (from $0 \mathrm{~h}$ to $24 \mathrm{~h}$ ), but then increase or decrease drastically as a consequence of proteolysis.

\subsubsection{Handling Effects on the Energy Metabolism and Associated Pathways Proteins}

Most of the bands related to energy metabolism found in the myofibrillar fraction were glycolytic enzymes (Figure 3), usually found in the sarcoplasmic fraction. Among them, only the band M19 (36.88 kDa), corresponding to Fructose-biphosphate aldolase A "ALDOA", was affected by the three factors studied: F, TL, and ageing time, showing higher intensity in meat from the Intensive rearing system $(p<0.01)$ and from the NM animals $(p<0.01)$, and a significant decrease along post-mortem ageing $(p<0.001)$ that starts at $8 \mathrm{~h}$ post-mortem in the meat from the Intensive treatment and at $24 \mathrm{~h}$ from the Extensive system (significant interaction $(p<0.01) \mathrm{F} \times \mathrm{t})$. Band M18 $(37.64 \mathrm{kDa})$, also identified as ALDOA, showed a significant post-mortem decrease. In contrast with these results in the myofibrillar fraction, previous studies in the same animals showed higher intensity of ALDOA $(37.1 \mathrm{kDa})$ in the sarcoplasmic subproteome of meat from the extensive reared animals [9]. ALDOA catalyzes the conversion of fructose 1, 6-diphosphate to glyceraldehyde 3-phosphate during glycolysis, therefore its lower intensity in meat from Intensive reared animals in the sarcoplasmic fraction can be associated with a faster glycogenolysis exhaustion or degradation of the enzyme in these animals that were found to be more susceptible to pre-slaughter stress [9]. However, it is also known that ALDOA in association with other metabolic enzymes, assists in the creation of cross-links between adjacent actin filaments or in binding troponin to the thin filaments, to enhance energy provision, where it is actively needed during contraction, hence affecting the distance between myofibrils, and therefore light scattering and tenderness [57]. This could at least partially explain the differences found between sarcoplasmic and myofibrillar ALDOA contents, as, due to the higher glycolytic metabolism of Intensive reared animals at slaughter, more energy provision may be needed for contraction and more ALDOA can be retained within the interstitial spaces of the myofibrils during the extraction. It is worthy to note that ALDOA was identified as a robust biomarker of beef tenderness (Figure 3C) [18] and of color variation [47]. 
Apart from ALDOA, Farm management did not affect significantly any of the other proteins from the energy metabolic pathway, however TL affected significantly to the band M12 (Pyruvate kinase PKM isoform X1 "PKM") with increased intensity $(p<0.01)$ in the meat from the NM group under a significant $\mathrm{F} \times \mathrm{TL}$ interaction $(p<0.001)$. This band was the only one corresponding to metabolic enzymes that did not show significant differences with post-mortem time. PKM is a glycolytic enzyme implicated in the last phases of the glycolysis that catalyzes the dephosphorylation of phosphoenolpyruvate to pyruvate, yielding one molecule of pyruvic acid and one of ATP. Previous studies have shown that animals mixed during transport and lairage are more affected by pre-slaughter stress and they have also been related to higher post-mortem glycolytic metabolism [9,58]. Moreover, lower abundance of PKM was previously found in myofibrillar subproteome of high pH24 meat [26]. Thus, the lower levels of PKM found in the myofibrillar fraction of mixed animals in the present study can be explained by the glycogen depletion occurring due to PSS caused by the mixing procedure before slaughter. This can lead to a decrease in the glycolysis rate after slaughter due to the early depletion of glycogen and a downregulation of proteins involved in the glycolytic pathway in conjunction with oxidative pathways driven by mitochondria (for review see Gagaoua et al. [22]).

The other metabolic enzymes, PFKM, ATP5F1B, and GAPDH, showed significant differences $(p<0.01)$ only with post-mortem time, with increasing band intensities during the early post-mortem until $24 \mathrm{~h}$ or 3 days post-mortem and decreasing afterwards. This reflects the cell metabolism behavior, with high levels of this proteins at early post-mortem due to the trigger of the glycolytic metabolism but decreasing later due to the impact of $\mathrm{pH}$ that might desaturate them or significantly reduce their activity.

\subsubsection{Handling Effects on the Heat Shock Proteins}

Overall, three bands from the myofibrillar subproteome were identified as members of the Heat Shock proteins (HSPs) family: M9 was identified as the large Heat shock $70 \mathrm{kDa}$ protein 1A "HSPA1A", and the other two (M30 and M33) as members of the small HSPs subfamily, identified as Heat Shock protein family B member 1 variant 1 "HSPB1" (also known as HSP27) and Alpha-crystallin B chain "CRYAB". Functional proteomic studies have confirmed differential expression of HSPs in meat from different breeds, handling systems and quality traits $[16,21,32,47,59,60]$. In the present study, all the HSPs bands showed significant changes along the post-mortem meat maturation, with a significant increase $(p<0.01)$ up to $24 \mathrm{~h}$ post-mortem followed by a progressive decrease afterwards in the case of HSPB1, a significant increase after three days $(p<0.001)$ for HSPA1A and a significant decrease $(p<0.001)$ after three days for CRYAB. Surprisingly, none of these bands were affected by management at farm, and the mixing treatment affected significantly only HSPB1 band that was more intense $(p<0.001)$ in meat from the non-Mixed group. Moreover, a significant interaction $\mathrm{F} \times \mathrm{TL}(p<0.001)$ was found for this band.

Among the small HSPs, HSPB1 is one of the most frequently related protein to beef tenderness but in different directions (positive or negative manner) depending on the studied factors (PSS, breed, gender, post-translational modifications (isoform), rearing factor, etc.), as explained by Gagaoua et al. [21]. HSPs exert protective functions as chaperone proteins from proteases, therefore they could reduce degradation of myofibrillar proteins [61]. Several studies reported positive relationship between degradation of HSPB1 and meat tenderness improvements, as degraded HSPs may no longer prevent irreversible damage to myofibrillar proteins $[1,60,62,63]$. Accordingly, our results showed higher intensity of HSPB1 band in the myofibrillar subproteome of meat from the E-NM treatment, which was the treatment that showed higher WBSF, and thus a lower tenderization rate. Moreover, the evolution of HSPB1 along meat ageing is in agreement with previous studies in bovine muscles $[50,64,65]$ that have demonstrated that muscle HSPB1 increases in abundance shortly after slaughter but decreases during meat storage. Similarly, our results showed a significant decrease $(p<0.001)$ of the large HSPA1A with post-mortem ageing. Members of the HSP70 family were previously found in the sarcoplasmic subproteome of 
these animals with a significant effect of Farm management, showing higher intensity in meat from the extensive reared animals [9]. Under stress situations, HSPA1A, which is an inducible protein that translocates and accumulates in the cytoskeletal and myofibrillar proteins in an attempt of stabilizing the muscle structure [40]. This HSP diffusion capacity between cellular fractions may explain the differences found between rearing treatments. As aforementioned, animals from intensive rearing system are suggested to be more susceptible to handling and pre-slaughter stress $[9,18]$ so that more HSP may translocate to myofibrils while in the extensively reared group more HSPA-A is probably easily removed and extracted from the sarcoplasmic fraction.

CRYAB was affected by post-mortem time showing a significant $(p<0.001)$ increase in intensity after seven days of storage. In contrast, previous studies demonstrate a decrease of intact CRYAB with ageing in total extracts from different muscles (Longissimus lumborum, Semimembranosus and Psoas major) of Angus x Simmental beef cattle [60]. Our results showing late post-mortem increases of this band could be explained by solubility changes due to protein modifications such as fragmentation, oxidation, precipitation, or aggregation thereby going from soluble to an insoluble state. This was previously pointed out by Bjarnadóttir et al. [32], who discovered that some of the small HSPs proteins increased their abundance in the insoluble protein fraction, possibly as a result of aggregation onto myofibrillar proteins, thereby following them during extraction. It is also important to note that CRYAB behaves also as a structural protein and therefore it can be susceptible of degradation along ageing.

\subsection{Relationship between Meat Quality Traits and the Significantly Changing Myofibrillar Proteins}

The correlations between the differential protein bands from the myofibrillar subproteome and meat quality traits, measured at different post-mortem times were analyzed, and significant correlations with color traits and meat toughness are shown in Tables 4 and 5 respectively.

In the present study beef color traits were correlated (Table 4) with two metabolic enzymes (PKM and ALDOA), two Heat Shock proteins (HSPA1A and HSPB1) and three structural proteins (DES, TNNI2 and MYLPF). This confirms the knowledge about the importance of cell glycolytic rate and its consequences on post-mortem modifications of proteins such as myosin, actin, troponin, and other metabolic proteins, particularly glycolytic enzymes in the sarcoplasm, and therefore influences the ultimate meat color.

A recent integromics study evidenced that both glycolytic enzymes and HSPs pathways have important roles in beef color determination where several relevant biomarkers were shortlisted [21]. Accordingly, PKM showed significant $(p<0.05)$ positive correlations with $L^{*}, b^{*}$ and $h^{*}$ and negative with $a^{*}$ and $C^{*}$. The highest correlation coefficients were found at $8 \mathrm{~h}$ post-mortem with $a^{*}(-0.850, p<0.01)$ and $h^{*}(0.800, p<0.01)$. ALDOA showed the highest correlations with $a^{*}$ and $h^{*}$ at 7 days post-mortem $(0.821, p<0.01$ and -0.695 , $p<0.05$, respectively). Other correlations were found between color traits and GAPDH $\left(0.701, p<0.05\right.$ with $a^{*}$ and $-0.705, p<0.01$ with $\left.h^{*}\right)$ at 7 days post-mortem. PKM and ALDOA may exert their effect on muscle color due to their involvement in the glycolytic pathway providing energy to the muscle contraction. They can also assist in the creation of crosslinks between actin filaments or in binding troponin to the thin filaments, hence affecting the distance between myofibrils and therefore light scattering [21,22,66-69]. In the case of HSPs, we found positive correlations between HSPA1A and $L^{*}$ and $h^{*}(+0.731, p<0.05$ at $8 \mathrm{~h}$ post-mortem) and negative between HSPB1 and $L^{*}$ and $b^{*}(-0.73, p<0.01$ at 7 days post-mortem). Many studies have related HSPs with color [70-72] probably due to their protective action against stress-induced denaturation of muscle proteins, that would affect reflectance, light scattering, and myoglobin, hence influencing color parameters [57,73-77]. 
Table 4. Significant Pearson correlations coefficients between myofibrillar subproteome bands and meat color traits.

\begin{tabular}{|c|c|c|c|c|c|c|c|c|c|c|c|c|c|c|c|c|c|}
\hline & & PFKM & HSPA1A & PKM & DES & $\begin{array}{c}\text { ALDOA } \\
\text { M18 }\end{array}$ & $\begin{array}{c}\text { ALDOA } \\
\text { M19 }\end{array}$ & GAPDH & TPM1 & LDB3 & FHL1 & $\begin{array}{c}\text { TNNT3 } \\
\text { M25 }\end{array}$ & $\begin{array}{c}\text { TNNT3 } \\
\text { M27 }\end{array}$ & HSPB1 & TNNI2 & CRYAB & MYLPF \\
\hline$L^{*}(60)$ & $\begin{array}{c}2 \mathrm{~h} \\
8 \mathrm{~h} \\
24 \mathrm{~h} \\
3 \mathrm{~d} \\
7 \mathrm{~d} \\
14 \mathrm{~d}\end{array}$ & & $\begin{array}{c}0.691 \text { * } \\
\mathbf{0 . 7 3 1} \text { ** }\end{array}$ & 0.613 * & $\begin{array}{l}0.608^{*} \\
0.615^{*} \\
0.599 \text { * }\end{array}$ & & 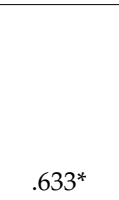 & -0.652 * & & -0.654 * & -0.588 * & 0.583 * & & $\begin{array}{l}-0.651 * \\
-0.581 * \\
-0.687 \text { * } \\
-0.777 *\end{array}$ & $\begin{array}{c}0.624^{*} \\
0.604^{*} \\
0.697^{*} \\
\mathbf{0 . 7 6 8} \text { ** }\end{array}$ & $-0.630^{*}$ & $\begin{array}{c}0.702 * \\
0.610^{*} \\
.578^{*}\end{array}$ \\
\hline$a^{*}(60)$ & $\begin{array}{c}2 \mathrm{~h} \\
8 \mathrm{~h} \\
24 \mathrm{~h} \\
3 \mathrm{~d} \\
7 \mathrm{~d} \\
14 \mathrm{~d}\end{array}$ & $\begin{array}{l}-0.588^{*} \\
-0.694^{*}\end{array}$ & & $\begin{array}{c}-0.695^{*} \\
-0.850 * \\
-0.675^{*} \\
-0.726^{*} \\
-0.585^{*}\end{array}$ & $-0.683 *$ & $\begin{array}{c}0.685^{*} \\
\mathbf{0 . 8 2 1}\end{array}$ & & 0.701 * & & & & $\begin{array}{l} \\
-0.592 * \\
-0.632\end{array}$ & $-0.686^{*}$ & & -0.581 * & & $\begin{array}{l}-0.593 \text { * } \\
-0.707 \text { * } \\
-0.611 \text { * }\end{array}$ \\
\hline$b^{*}(60)$ & $\begin{array}{c}2 \mathrm{~h} \\
8 \mathrm{~h} \\
24 \mathrm{~h} \\
3 \mathrm{~d} \\
7 \mathrm{~d} \\
14 \mathrm{~d} \\
\end{array}$ & & $\begin{array}{l}0.645^{*} \\
0.612 \text { * }\end{array}$ & $0.581^{*}$ & $0.588^{*}$ & & & & $0.606^{*}$ & $\begin{array}{l}-0.633 \text { * } \\
-0.664 \text { * }\end{array}$ & -0.650 * & & & $\begin{array}{c}-0.624^{*} \\
-0.738^{* *}\end{array}$ & $\begin{array}{l}0.627^{*} \\
0.683 \text { * } \\
0.634 \text { * }\end{array}$ & -0.597 * & $0.608^{*}$ \\
\hline$C^{*}(60)$ & $\begin{array}{c}2 \mathrm{~h} \\
8 \mathrm{~h} \\
24 \mathrm{~h} \\
3 \mathrm{~d} \\
7 \mathrm{~d} \\
14 \mathrm{~d}\end{array}$ & $-0.714^{*}$ & & $\begin{array}{l}-0.605 \text { * } \\
-0.613 \text { * } \\
-0.637 \text { * }\end{array}$ & -0.584 * & 0.651 * & $\begin{array}{l}-0.592 * \\
-0.644^{*} \\
-0.599 *\end{array}$ & & & & & & $-0.634^{*}$ & & & & \\
\hline$h^{*}(60)$ & $\begin{array}{c}2 \mathrm{~h} \\
8 \mathrm{~h} \\
24 \mathrm{~h} \\
3 \mathrm{~d} \\
7 \mathrm{~d} \\
14 \mathrm{~d}\end{array}$ & & $\begin{array}{l}0.592 \text { * } \\
0.700 \text { * }\end{array}$ & $\begin{array}{l}\mathbf{0 . 8 0 0 * *} \\
0.670^{*} \\
0.676^{*}\end{array}$ & $0.588^{*}$ & $-0.695^{*}$ & & $-0.751^{* *}$ & & $-0.617^{*}$ & & $\begin{array}{l}0.626^{*} \\
0.618^{*}\end{array}$ & & -0.641 * & $\begin{array}{c}0.610^{*} \\
0.755 \text { ** }\end{array}$ & & $\begin{array}{c}\mathbf{0 . 7 4 1} \mathbf{1}^{* *} \\
0.578^{*} \\
\mathbf{0 . 7 2 1} \text { ** } \\
0.654^{*}\end{array}$ \\
\hline
\end{tabular}

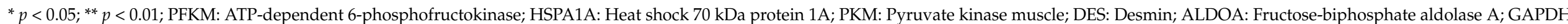

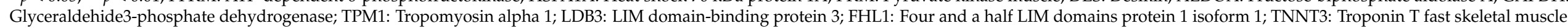

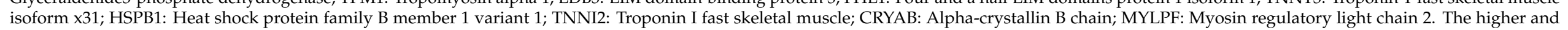
significant correlation coefficients are in bold. 
Table 5. Significant Pearson correlations coefficients between myofibrillar subproteome bands and tenderness evaluated by Warner-Bratzler shear force and tenderization rate (\%).

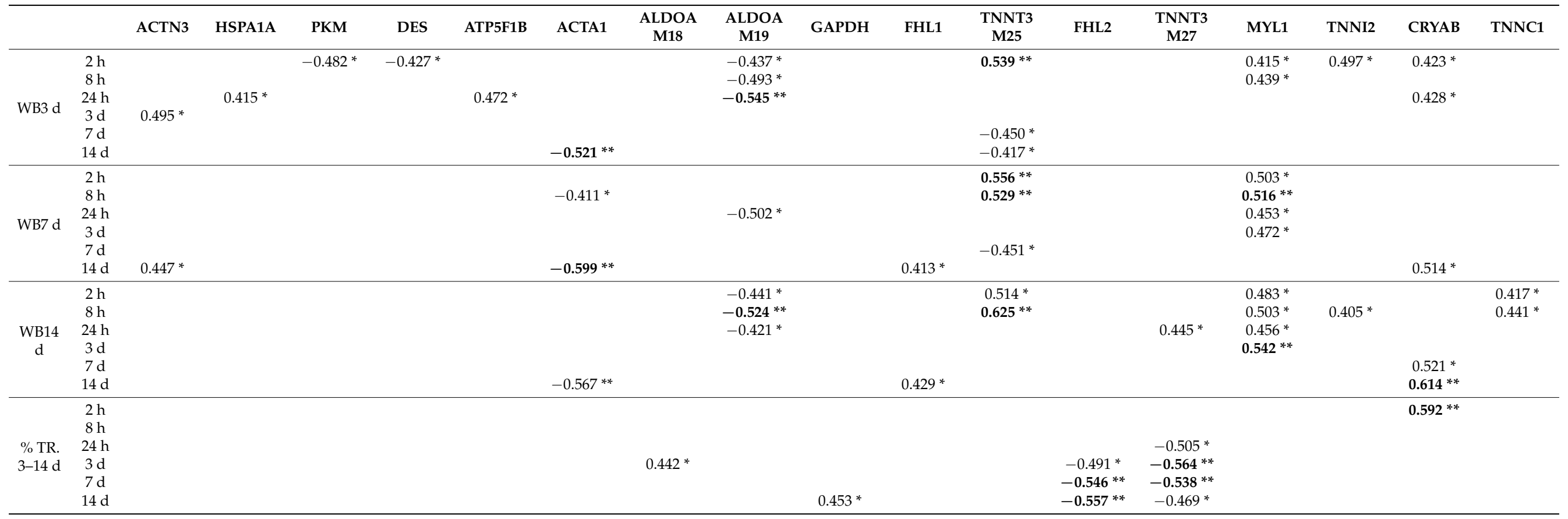

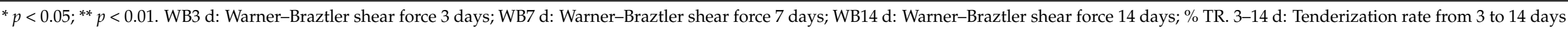

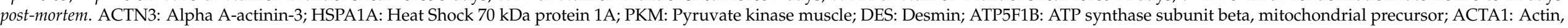

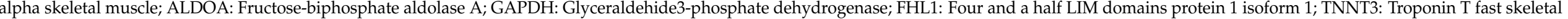

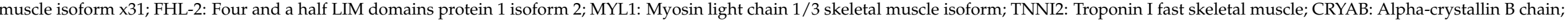
TNNC1: Troponin C. The higher and significant correlation coefficients are in bold. 
Finally, strong positive correlations were found between some structural proteins and color, such as between MYLPF with $L^{*}$ and $h^{*}$ at $2 \mathrm{~h}$ post-mortem $(0.7, p<0.01)$ and between TNNI2 and $L^{*}$ and $h^{*}$ at 3 days post-mortem $(0.75, p<0.01)$, while negative correlations were found between $a^{*}$ and DES at $2 \mathrm{~h}$ post-mortem $(-0.683, p<0.05)$ and MYLPF at 3 days post-mortem $(-0.707, p<0.01)$. Hughes et al. [76] found that meat color was not determined only by chromatic heme pigments, but also by the physical structure and achromatic light scattering properties of the muscle. Therefore, the effect of structural proteins in meat color is related to their denaturation and degradation during the post-mortem process that affect the protein density along the sarcomere, and therefore light scattering from the structural elements as evidenced in the recent integromics proteomics meta-analyses of beef color and dark-cutting beef by Gagaoua et al. [22,47]. The current insights as revealed by both proteomics and conventional biochemical studies were further recently discussed by Purslow et al. [77]. The authors stated that it is increasingly likely that omics techniques, including proteomics, will be used to discover more of the complex interactions between pathways behind the qualities of meat and their determination.

Regarding tenderness, a total of 18 bands showed significant correlations with WBSF and/or with meat tenderization rate (\% of WBSF decrease from 3 days to 14 days (Table 5 ). ACTA1, TNNT3, MYL1, ALDOA, and CRYAB were correlated with tenderness. These proteins showed the highest correlations with WBSF during the first $24 \mathrm{~h}$ post-mortem, being negative in the case of ALDOA, mainly with WBSF 3 days and ALDOA measured at $24 \mathrm{~h}$ post-mortem $(-0.549, p<0.05)$, and positive in the case of TNNT3 and WBSF at 14 days post-mortem $(0.625, p<0.01)$. Thus, these findings support the previous knowledge of the importance of these proteins (Figure 3C) as early biomarkers of meat tenderization. In agreement with these results, ALDOA was positively associated with tenderness [18]. Finally, and with respect to tenderness, CRYAB, showed a positive correlation at $2 \mathrm{~h}$ postmortem with the tenderization rate from 3 to 14 days post-mortem $(0.592, p<0.01)$. Increased CRYAB levels were associated with delayed myofibril degradation in beef with ultimate $\mathrm{pH}<5.7[61]$

With the aim to summarize the complex relationships between meat quality traits and the myofibrillar subproteome, a PCA was performed including only the variables with higher correlation loadings (over 50\% of explained variance). Figure 4 shows the biplot obtained by PCA between variables (loadings), individual meat samples (scores), and treatments (centroids). The first PC1 and PC2 explained $62 \%$ of the variability. The PC1 separated in the positive side the meat samples from the Extensive treatment, with higher meat WBSF values and overexpression of MYL1 at 2, 8, and $24 \mathrm{~h}$, MYLPF at $24 \mathrm{~h}$, LDB3 at 3 days, FHL2 at 7 and 14 days, TNNT3 $(29 \mathrm{kDa})$ at $8 \mathrm{~h}$, TNNT3 $(27 \mathrm{kDa})$ at 3 days, TNNI2 at $24 \mathrm{~h}$ and CRYAB at $2 \mathrm{~h}$. The meat samples from the Intensive treatment were located in the negative side, showing higher $b^{*}$ values, $h^{*}$ and $C^{*}$ and ACTA1 at $8 \mathrm{~h}$ post-mortem.

Multivariate analysis showed that the handling factors (F and TL) had a clear effect in the different variables analyzed. Thus, animal's farm management produced a clear separation between meat samples from animals reared under Intensive or Extensive systems. On the other hand, the effect of Mixing animals during Transport and Lairage was significant in the intensively reared animals with a clear separation in two groups: (1) meat of the I-NM animals with lower WBSF values and higher intensity of the ACTA1 band at 8 $\mathrm{h}$ post-mortem; and (2) meat of the I-M animals with higher $b^{*}, h^{*}$, and $C^{*}$. Our previous studies pointed out that these I-M animals suffered from higher PSS as they showed higher serum haptoglobin and glucose levels at slaughter and lower muscle ATP levels, thus resulting in the blockage of the muscle antioxidant defense and slower post-mortem autophagic rate [9,18]. In fact, response to oxidative stress was found as a significant enriched term in this study (Figure 3B), which need further studies in the future to better elucidate the underlying mechanisms about its role in relation to the factors we investigated in this study. 


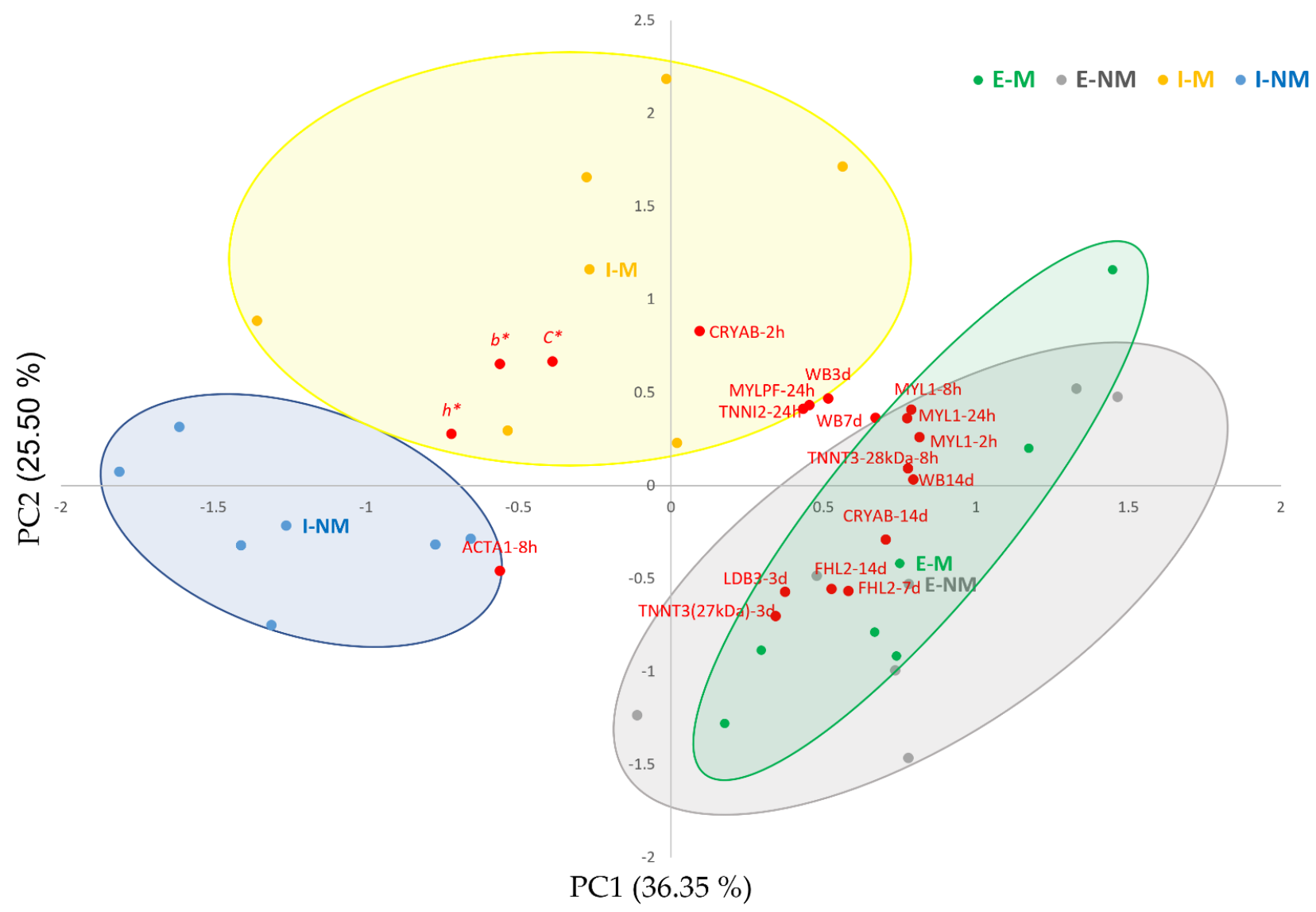

Figure 4. Biplot of variables and individuals (meat samples). The centroids of the animal treatments are shown in squares denoted with codes: I-M (Intensive-Mixed), I-NM (Intensive-Non-Mixed), E-M (Extensive Mixed), E-NM (ExtensiveNon-Mixed). Individual samples are shown in yellow bullets (I-M), blue bullets (I-NM), green bullets (E-M) and grey bullets (E-NM). WB3 d: Warner-Bratzler Shear Force at 3 days, WB7 d: Warner-Bratzler Shear Force at 7 days, WB14 d: Warner-Bratzler Shear Force at 14 days; $b^{*}$ : yellowness; $C^{*}$ : Chroma; $h^{*}$ : hue angle; CRYAB: Alpha-crystallin B chain; MYL1: Myosin light chain 1/3 skeletal muscle isoform; MYLPF: Myosin regulatory light chain 2, skeletal muscle isoform; TNNT3: Troponin T, fast skeletal muscle isoform X31; TNNI2: Troponin I, fast skeletal muscle; LDB3: LIM domain-binding protein 3 isoform X5; FHL2: Four and a half LIM domains protein 1 isoform 2; ACTA1: Actin, alpha skeletal muscle. 2 h: 2 h post-mortem, 8 h: 8 h post-mortem; 24 h: 24 h post-mortem; 3 d: 3 days post-mortem; 7 d: 7 days post-mortem.

Within the extensively reared animals, the effect of social mixing was not very clear as mixed and non-mixed animals were overlapped in the positive side of the PC1, indicating a lower effect of mixing unfamiliar animals, as previously described [9]. It is difficult to determine if these differences between treatments are due to differences in diet, physical activity or higher PSS derived from the different animal's handling treatments, but there are clear differences and the changes they produce in the myofibrillar subproteome at early post-mortem could provide putative biomarkers of the final meat quality.

\section{Conclusions}

The findings of this study confirmed that meat quality of young "Asturiana de los Valles" bulls is affected by handling practices at Farm and during Transport and Lairage before slaughter and during the tenderization of the meat. At the farm level, the production system (Intensive vs. Extensive) significantly affected meat color parameters $\left(L^{*}, b^{*}, C^{*}\right.$, and $\left.h^{*}\right)$, highlighting that the meat from the Extensive treatment was brownish and darker. The Transport and Lairage factor (Mixed vs. Non-Mixed) affected also color traits mainly redness $\left(a^{*}\right)$ and Chroma $\left(C^{*}\right)$ leading to lower values in non-mixed animals. The tenderization rate of the meats of the investigated groups was higher but delayed in the meat samples from I-M animals. The comparative proteomics extended our knowledge and revealed 
that Farm, Transport/Lairage and post-mortem ageing has huge but different effects on the post-mortem muscle myofibrillar subproteome. The major pathway that was impacted by this factor was related to muscle structure. In fact, farm management affected six structural proteins (MYBPC2, TNNT3, MYL1, ACTA1, LDB3, and FHL2) and one metabolic enzyme (ALDOA) while Transport and Lairage prior to slaughter induced changes in five structural protein bands (MYBPC2, TNNT3, TNNI2, MYL1, and MYLPF), two metabolic enzymes (PKM and ALDOA), and one Heat shock protein (HSPB1).

Post-mortem ageing was the most important factor affecting the myofibrillar proteome, among the different handling practices confirming the importance of monitoring subproteome changes along meat ageing for an accurate understanding of the effects. Several correlations were found between the protein changing in this trial at early post-mortem times with meat color and tenderness parameters (PKM, ALDOA, HSPA1A, HSPB1, CRYAB, DES, TNNT3, TNNI2, and MYLPF), confirming that they could be used as meat quality biomarkers in comparison to the largest and recent beef tenderness biomarkers database recently published by Gagaoua et al. [21].

Author Contributions: Conceptualization: M.O., V.S., M.G. and A.C.-M.; methodology: L.G.-B., F.D., M.O. and V.S.; investigation: L.G.-B., F.D., M.J.G.-E. and Y.D.; formal analysis: V.S. and M.G.; data curation: L.G.-B.; writing—original draft preparation: V.S.; writing—review and editing: M.O., M.G. and A.C.-M. visualization. L.G.-B. and M.G.; supervision. M.O.; funding acquisition V.S. and M.O. All authors have read and agreed to the published version of the manuscript.

Funding: This research was funded by Instituto Nacional de Investigación y Tecnología Agraria y Alimentaria (INIA) and FEDER funds under the project RTA2014-00034-C04-01, and grant RTI2018096162-RC21 funded by MCIN/AEI/10.13039/501100011033 and by “ERDF a way making Europe". The APC was funded by RTI2018-096162-RC21. F.D. acknowledges the contract PEJ-2014P-01094 awarded by MINECO (Spain). L.G.-B acknowledges her grant PRE2019-091053 funded by MCIN/AEI/10.13039/501100011033 and by ESF "investing in your future".

Institutional Review Board Statement: The consideration of the ethical and welfare aspects by the Animal Care \& Ethics Committee (ACEC) was not required for the development of the current study, since the animals were subjected to standard production practices during growing and finishing phases in compliance with the Spanish Law 32/2007 for the care of animals during their exploitation, transport, experimentation, and sacrifice. No additional measures were required.

Informed Consent Statement: Not applicable.

Data Availability Statement: Data available on request.

Acknowledgments: We thank the staff of the Area of Livestock Production Systems from SERIDA and the staff from ASEAVA for skilled management of Animals. Mohammed Gagaoua acknowledges the funding support of the Marie Sklodowska-Curie grant agreement No. 713654 under the project number MF20180029.

Conflicts of Interest: The authors declare no conflict of interest. The funders had no role in the design of the study; in the collection, analyses, or interpretation of data; in the writing of the manuscript or in the decision to publish the results.

\section{References}

1. Picard, B.; Gagaoua, M.; Micol, D.; Cassar-Malek, I.; Hocquette, J.F.; Terlouw, C.E. Inverse relationships between biomarkers and beef tenderness according to contractile and metabolic properties of the muscle. J. Agric. Food Chem. 2014, 62, 9808-9818. [CrossRef] [PubMed]

2. Gagaoua, M.; Monteils, V.; Picard, B. Data from the farmgate-to-meat continuum including omics-based biomarkers to better understand the variability of beef tenderness: An integromics approach. J. Agric. Food Chem. 2018, 66, 13552-13563. [CrossRef]

3. López-Pedrouso, M.; Rodríguez-Vázquez, R.; Purriños, L.; Oliván, M.; García-Torres, S.; Sentandreu, M.Á.; Lorenzo, J.M.; Zapata, C.; Franco, D. Sensory and physicochemical analysis of meat from bovine breeds in different livestock production systems, pre-slaughter handling conditions, and ageing time. Foods 2020, 9, 176. [CrossRef]

4. Gagaoua, M.; Picard, B.; Soulat, J.; Monteils, V. Clustering of sensory eating qualities of beef: Consistencies and differences within carcass, muscle, animal characteristics and rearing factors. Livest. Sci. 2018, 214, 245-258. [CrossRef] 
5. Priolo, A.; Micol, D.; Agabriel, J. Effects of grass feeding systems on ruminant meat colour and flavour. A review. Anim. Res. 2001, 50, 185-200. [CrossRef]

6. Andersen, H.J.; Oksbjerg, N.; Young, J.F.; Therkildsen, M. Feeding and meat quality-A future approach. Meat Sci. 2005, 70, 543-554. [CrossRef]

7. Bouissou, M.F.; Boissy, A.; le Neindre, P.; Veissier, I. The social behaviour of cattle. Soc. Behav. Farm Anim. 2001, 113-145. [CrossRef]

8. Marco-Ramell, A.; Arroyo, L.; Saco, Y.; García-Heredia, A.; Camps, J.; Fina, M.; Piedrafita, J.; Bassols, A. Proteomic analysis reveals oxidative stress response as the main adaptative physiological mechanism in cows under different production systems. J. Proteom. 2012, 75, 4399-4411. [CrossRef]

9. Díaz, F.; Díaz-Luis, A.; Sierra, V.; Diñeiro, Y.; González, P.; García-Torres, S.; Oliván, M. What functional proteomic and biochemical analysis tell us about animal stress in beef? J. Proteom. 2020, 218, 103722. [CrossRef] [PubMed]

10. Terlouw, E.M.C.; Picard, B.; Deiss, V.; Berri, C.; Hocquette, J.F.; Lebret, B.; Lefèvre, F.; Hamill, R.; Gagaoua, M. Understanding the determination of meat quality using biochemical characteristics of the muscle: Stress at slaughter and other missing keys. Foods 2021, 10, 84. [CrossRef] [PubMed]

11. Bøe, K.E.; Færevik, G. Grouping and social preferences in calves, heifers and cows. Appl. Anim. Behav. Sci. 2003, 80, 175-190. [CrossRef]

12. Disanto, C.; Celano, G.; Varvara, M.; Fusiello, N.; Fransvea, A.; Bozzo, G.; Celano, G.V. Stress factors during cattle slaughter. Ital J. Food Saf. 2014, 3, 143-144. [CrossRef]

13. Rubio-González, A.; Potes, Y.; Illán-Rodríguez, D.; Vega-Naredo, I.; Sierra, V.; Caballero, B.; Fàbrega, E.; Velarde, A.; Dalmau, A.; Oliván, M.; et al. Effect of animal mixing as a stressor on biomarkers of autophagy and oxidative stress during pig muscle maturation. Animal 2015, 9, 1188-1194. [CrossRef] [PubMed]

14. Potes, Y.; Oliván, M.; Rubio-González, A.; de Luxán-Delgado, B.; Díaz, F.; Sierra, V.; Arroyo, L.; Peña, R.; Bassols, A.; González, J.; et al. Pig cognitive bias affects the conversion of muscle into meat by antioxidant and autophagy mechanisms. Animal 2017, 11, 2027-2035. [CrossRef] [PubMed]

15. Franco, D.; Mato, A.; Salgado, F.J.; López-Pedrouso, M.; Carrera, M.; Bravo, S.; Parrado, M.; Gallardo, J.M.; Zapata, C. Tackling proteome changes in the Longissimus thoracis bovine muscle in response to pre-slaughter stress. J. Proteomics 2015, 122, 73-85. [CrossRef] [PubMed]

16. Díaz-Luis, A.; Díaz, F.; Diñeiro, Y.; González-Blanco, L.; Arias, E.; Coto-Montes, A.; Oliván, M.; Sierra, V. Nuevos indicadores de carnes (DFD): Estrés oxidativo, autofagia y apoptosis. ITEA 2020, 117, 3-18. [CrossRef]

17. Fuente-García, C.; Aldai, N.; Sentandreu, E.; Oliván, M.; Franco, D.; García-Torres, S.; Barron, L.J.R.; Sentandreu, M.Á. Caspase activity in post-mortem muscle and its relation to cattle handling practices. J. Sci. Food Agric. 2021, 101, 6258-6264. [CrossRef]

18. García-Torres, S.; Cabeza de Vaca, M.; Tejerina, D.; Romero-Fernández, M.P.; Ortiz, A.; Franco, D.; Sentandreu, M.Á.; Oliván, M. Assessment of stress by serum biomarkers in calves and their relationship to ultimate $\mathrm{pH}$ as an indicator of meat quality. Animals 2021, 11, 2291. [CrossRef] [PubMed]

19. Ouali, A.; Gagaoua, M.; Boudida, Y.; Becila, S.; Boudjellal, A.; Herrera-Mendez, C.; Sentandreu, M.Á. Biomarkers of meat tenderness: Present knowledge and perspectives in regard to our current understanding of the mechanisms involved. Meat Sci. 2013, 95, 854-870. [CrossRef]

20. Picard, B.; Gagaoua, M. Chapter 11-proteomic investigations of beef tenderness. In Proteomics in Food Science: From Farm to Fork; Colgrave, M.L., Ed.; Academic Press: Cambridge, MA, USA, 2017; pp. 177-197. [CrossRef]

21. Gagaoua, M.; Terlouw, E.M.C.; Mullen, A.M.; Franco, D.; Warner, R.D.; Lorenzo, J.M.; Purslow, P.P.; Gerrard, D.; Hopkins, D.L.; Troy, D.; et al. Molecular signatures of beef tenderness: Underlying mechanisms based on integromics of protein biomarkers from multi-platform proteomics studies. Meat Sci. 2021, 172, 108311. [CrossRef] [PubMed]

22. Gagaoua, M.; Warner, R.B.; Purslow, P.; Ramanathan, R.; Mullen, A.M.; López-Pedrouso, M.; Franco, D.; Lorenzo, J.M.; Tomasevic, I.; Picard, B.; et al. Dark-cutting beef: A brief review and an integromics meta-analysis at the proteome level to decipher the underlying pathways. Meat Sci. 2021, 181, 108611. [CrossRef]

23. Warner, R.; Wheeler, T.L.; Ha, M.; Li, X.; Bekhit, A.E.D.; Morton, J.; Vaskoska, R.; Dunshea, F.; Liu, R.; Purslow, P.; et al. Meat tenderness: Advances in biology, biochemistry, molecular mechanisms and new technologies. Meat Sci. 2021, 108657. [CrossRef]

24. Zapata, I.; Zerby, H.N.; Wick, M. Functional proteomic analysis predicts beef tenderness and the tenderness differential. J. Agric. Food Chem. 2009, 57, 4956-4963. [CrossRef] [PubMed]

25. Sierra, V.; Fernández-Suárez, V.; Castro, P.; Osoro, K.; Vega-Naredo, I.; García-Macía, M.; Rodríguez-Colunga, P.; Coto-Montes, A.; Oliván, M. Identification of biomarkers of meat tenderisation and its use for early classification of Asturian beef into fast and late tenderising meat. J. Sci. Food Agric. 2012, 92, 2727-2740. [CrossRef]

26. Fuente-Garcia, C.; Sentandreu, E.; Aldai, N.; Oliván, M.; Sentandreu, M.Á. Characterization of the myofibrillar proteome as a way to better understand differences in bovine meats having different ultimate $\mathrm{pH}$ values. J. Proteomics 2020, 20, 2000012. [CrossRef]

27. Gagaoua, M. The path from protein profiling to biomarkers: The potential of proteomics and data integration in beef quality research. IOP Conf. Ser. Earth Environ. Sci. 2021, 854, 012029. [CrossRef]

28. Piedrafita, J.; Quintanilla, R.; Sañudo, C.; Olleta, J.L.; Campo, M.M.; Panea, B.; Renand, G.; Turin, F.; Jabet, S.; Osoro, K.; et al. Carcass quality of ten beef cattle breeds of the south-west of europe. Livest. Prod. Sci. 2003, 82, 1-13. [CrossRef] 
29. Sierra, V.; Guerrero, L.; Fernández-Suárez, V.; Martínez, A.; Castro, P.; Osoro, K.; Rodríguez-Colunga, M.J.; Coto-Montes, A.; Oliván, M. Eating quality of beef from biotypes included in the PGI "Ternera Asturiana" showing distinct physicochemical characteristics and tenderization pattern. Meat Sci. 2010, 86, 343-351. [CrossRef]

30. Mapama, I.G.P. Ternera Asturiana. Available online: https://www.mapa.gob.es/es/alimentacion/temas/calidad-diferenciada/ dop-igp/carnes/IGP_Ternera_Asturiana.aspx (accessed on 7 August 2021).

31. AMSA (American Meat Science Association). Meat Color Measurement Guidelines, Champaign, IL, USA, 2017. Available online: http:/ / www.meatscience.org (accessed on 10 October 2021).

32. Bjarnadóttir, S.G.; Hollung, K.; Faergestad, E.M.; Veiseth-Kent, E. Proteome changes in bovine Longissimus thoracis muscle during the first $48 \mathrm{~h}$ postmortem: Shifts in energy status and myofibrillar stability. J. Agric. Food Chem. 2010, 58, 7408-7414. [CrossRef]

33. Bradford, M.M. A rapid and sensitive method for the quantitation of microgram quantities of protein utilizing the principle of protein-dye binding. Anal. Biochem. 1976, 72, 248-254. [CrossRef]

34. Gagaoua, M.; Troy, D.; Mullen, A.M. The extent and rate of the appearance of the major 110 and $30 \mathrm{kDa}$ proteolytic fragments during post-mortem aging of beef depend on the glycolysing rate of the muscle and aging time: An LC-MS/MS approach to decipher their proteome and associated pathways. J. Agric. Food Chem. 2021, 69, 602-614. [CrossRef]

35. Vestergaard, M.; Oksbjerg, N.; Henckel, P. Influence of feeding intensity, grazing and finishing feeding on muscle fibre characteristics and meat colour of semitendinosus, longissimus dorsi and supraspinatus muscles of young bulls. Meat Sci. 2000, 54, 177-185. [CrossRef]

36. Realini, C.E.; Duckett, S.K.; Brito, G.W.; dalla Rizza, M.; de Mattos, D. Effect of pasture vs. concentrate feeding with or without antioxidants on carcass characteristics, fatty acid composition, and quality of Uruguayan beef. Meat Sci. 2004, 66, 567-577. [CrossRef]

37. Gagaoua, M.; Monteils, V.; Couvreur, S.; Picard, B. Identification of biomarkers associated with the rearing practices, carcass characteristics, and beef quality: An integrative approach. J. Agric. Food Chem. 2017, 65, 8264-8278. [CrossRef]

38. Vestergaard, M.; Therkildsen, M.; Henckel, P.; Jensen, L.R. Influence of feeding intensity, grazing and finishing feeding on meat and eating quality of young bulls and the relationship between muscle fibre characteristics, fibre fragmentation and meat tenderness. Meat Sci. 2000, 54, 187-195. [CrossRef]

39. Nuernberg, K.; Dannenberger, D.; Nuernberg, G.; Ender, K.; Voigt, J.; Scollan, N.D.; Wood, J.D.; Nute, G.R.; Richardson, R.I. Effect of a grass-based and a concentrate feeding system on meat quality characteristics and fatty acid composition of Longissimus muscle in different cattle breeds. Livest. Prod. Sci. 2005, 94, 137-147. [CrossRef]

40. Laville, E.; Sayd, T.; Morzel, M.; Blinet, S.; Chambon, C.; Lepetit, J.; Renand, G.; Hocquette, J.F. Proteome changes during meat aging in tough and tender beef suggest the importance of apoptosis and protein solubility for beef aging and tenderization. J. Agric. Food Chem. 2009, 57, 10755-10764. [CrossRef]

41. Paulsen, G.; Vissing, K.; Kalhovde, J.M.; Ugelstad, I.; Bayer, M.L.; Kadi, F.; Schjerling, P.; Hallén, J.; Raastad, T. Maximal eccentric exercise induces a rapid accumulation of small heat shock proteins on myofibrils and a delayed HSP70 response in humans. Am. J. Physiol. Regul. Integr. Comp. Physiol. 2007, 293, 844-853. [CrossRef] [PubMed]

42. González-Blanco, L.; Diñeiro, Y.; Díaz-Luis, A.; Coto-Montes, A.; Oliván, M.; Sierra, V. Impact of extraction method on the detection of quality biomarkers in normal vs. DFD meat. Foods 2021, 10, 1097. [CrossRef]

43. Ho, C.Y.; Stromer, M.H.; Robson, R.M. Identification of the $30 \mathrm{kDa}$ polypeptide in post mortem skeletal muscle as a degradation product of troponin-T. Biochimie 1994, 76, 369-375. [CrossRef]

44. Kemp, C.M.; Sensky, P.L.; Bardsley, R.G.; Buttery, P.J.; Parr, T. Tenderness-An enzymatic view. Meat Sci. 2010, 84, 248-256. [CrossRef]

45. Picard, B.; Gagaoua, M. Meta-proteomics for the discovery of protein biomarkers of beef tenderness: An overview of integrated studies. Food Res. Int. 2020, 127, 108739. [CrossRef] [PubMed]

46. Flashman, E.; Redwood, C.; Moolman-Smook, J.; Watkins, H. Cardiac myosin binding protein C: Its role in physiology and disease. Circ. Res. 2004, 94, 1279-1289. [CrossRef] [PubMed]

47. Guillemin, N.; Bonnet, M.; Jurie, C.; Picard, B. Functional analysis of beef tenderness. J. Proteomics 2011, 75, 352-365. [CrossRef]

48. Gagaoua, M.; Hughes, J.; Terlouw, E.M.C.; Warner, R.D.; Purslow, P.P.; Lorenzo, J.M.; Picard, B. Proteomic biomarkers of beef colour. Trends Food Sci. Technol. 2020, 101, 234-252. [CrossRef]

49. Wu, G.; Clerens, S.; Farouk, M.M. LC MS/MS identification of large structural proteins from bull muscle and their degradation products during post mortem storage. Food Chem. 2014, 150, 137-144. [CrossRef]

50. Huff-Lonergan, E.; Zhang, W.; Lonergan, S.M. Biochemistry of postmortem muscle-Lessons on mechanisms of meat tenderization. Meat Sci. 2010, 86, 184-195. [CrossRef] [PubMed]

51. Jia, X.; Hollung, K.; Therkildsen, M.; Hildrum, K.I.; Bendixen, E. Proteome analysis of early post-mortem changes in two bovine muscle types: M. longissimus dorsi and M. semitendinosis. J. Proteom. 2006, 6, 936-944. [CrossRef]

52. Sawdy, J.C.; Kaiser, S.A.; St-Pierre, N.R.; Wick, M.P. Myofibrillar 1-D fingerprints and myosin heavy chain MS analyses of beef loin at $36 \mathrm{~h}$ postmortem correlate with tenderness at 7 days. Meat Sci. 2004, 67, 421-426. [CrossRef]

53. Morzel, M.; Terlouw, C.; Chambon, C.; Micol, D.; Picard, B. Muscle proteome and meat eating qualities of Longissimus thoracis of "blonde d'Aquitaine" young bulls: A central role of HSP27 isoforms. Meat Sci. 2008, 78, 297-304. [CrossRef]

54. Zhou, Q.; Chu, P.H.; Huang, C.; Cheng, C.F.; Martone, M.E.; Knoll, G.; Shelton, G.D.; Evans, S.; Chen, J. Ablation of Cypher, a PDZ-LIM domain Z-line protein, causes a severe form of congenital myopathy. J. Cell Biol. 2001, 155, 605-612. [CrossRef] 
55. Shathasivam, T.; Kislinger, T.; Gramolini, A.O. Genes, proteins and complexes: The multifaceted nature of FHL family proteins in diverse tissues. J. Cell Mol. Med. 2021, 14, 2702-2720. [CrossRef] [PubMed]

56. Morzel, M.; Chambon, C.; Hamelin, M.; Sante-Lhoutellier, V.; Sayd, T.; Monin, G. Proteome changes during pork meat ageing following use of two different pre-slaughter handling procedures. Meat Sci. 2004, 67, 689-696. [CrossRef]

57. Gagaoua, M.; Bonnet, M.; Ellies-Oury, M.P.; de Koning, L.; Picard, B. Reverse phase protein arrays for the identification/validation of biomarkers of beef texture and their use for early classification of carcasses. Food Chem. 2018, 250, 245-252. [CrossRef]

58. Hughes, J.; Clarke, F.; Li, Y.; Purslow, P.; Warner, R. Differences in light scattering between pale and dark beef Longissimus thoracis muscles are primarily caused by differences in the myofilament lattice, myofibril and muscle fibre transverse spacings. Meat Sci. 2019, 149, 96-106. [CrossRef] [PubMed]

59. Oliván, M.; Fernández-Suárez, V.; Díaz-Martínez, F.; Sierra, V.; Coto-Montes, A.; Luxán-Delgado, B.; Peña, R.; Bassols, A.; Fàbrega, E.; Dalmau, A.; et al. Identification of biomarkers of stress in meat of pigs managed under different mixing treatments. $\mathrm{Br}$. Biotechnol. J. 2016, 11, 1-13. [CrossRef]

60. Yu, J.; Tang, S.; Bao, E.; Zhang, M.; Hao, Q.; Yue, Z. The effect of transportation on the expression of heat shock proteins and meat quality of M. longissimus dorsi in pigs. Meat Sci. 2009, 83, 474-478. [CrossRef]

61. Ma, D.; Kim, Y.H.B. Proteolytic changes of myofibrillar and small heat shock proteins in different bovine muscles during aging: Their relevance to tenderness and Water-holding capacity. Meat Sci. 2020, 163, 108090. [CrossRef]

62. Lomiwes, D.; Hurst, S.M.; Dobbie, P.; Frost, D.A.; Hurst, R.D.; Young, O.A.; Farouk, M.M. The protection of bovine skeletal myofibrils from proteolytic damage post-mortem by small heat shock proteins. Meat Sci. 2014, 97, 548-557. [CrossRef]

63. Balan, P.; Kim, Y.H.; Blijenburg, R. Small heat shock protein degradation could be an indicator of the extent of myofibrillar protein degradation. Meat Sci. 2014, 97, 220-222. [CrossRef] [PubMed]

64. Cramer, T.; Penick, M.L.; Waddell, J.N.; Bidwell, C.A.; Kim, Y.H.B. A new insight into meat toughness of callipyge lamb loins-The relevance of anti-apoptotic systems to decreased proteolysis. Meat Sci. 2018, 140, 66-71. [CrossRef] [PubMed]

65. Jia, X.; Hildrum, K.I.; Westad, F.; Kummen, E.; Aass, L.; Hollung, K. Changes in enzymes associated with energy metabolism during the early post-mortem period in Longissimus thoracis bovine muscle analyzed by proteomics. J. Proteome Res. 2006, 5, 1763-1769. [CrossRef]

66. Jia, X.H.; Ekman, M.; Grove, H.; Faergestad, E.M.; Aass, L.; Hildrum, K.I.; Hollung, K. Proteome changes in bovine Longissimus thoracis muscle during the early post-mortem storage period. J. Proteome Res. 2007, 6, 2720-2731. [CrossRef] [PubMed]

67. Canto, A.C.; Suman, S.P.; Nair, M.N.; Li, S.; Rentfrow, G.; Beach, C.M.; Silva, T.J.; Wheeler, T.L.; Shackelford, S.D.; Grayson, A.; et al. Differential abundance of sarcoplasmic proteome explains animal effect on beef Longissimus lumborum color stability. Meat Sci. 2015, 102, 90-98. [CrossRef]

68. Wu, W.; Gao, X.G.; Dai, Y.; Fu, Y.; Li, X.M.; Dai, R.T. Post-mortem changes in sarcoplasmic proteome and its relationship to meat color traits in M. semitendinosus of Chinese Luxi yellow cattle. Food Res. Int. 2015, 72, 98-105. [CrossRef]

69. Wu, W.; Yu, Q.Q.; Fu, Y.; Tian, X.J.; Jia, F.; Li, X.M.; Dai, R.T. Towards muscle specific meat color stability of Chinese Luxi yellow cattle: A proteomic insight into post-mortem storage. J. Proteomics 2016, 147, 108-118. [CrossRef]

70. Hughes, J.; Clarke, F.; Purslow, P.; Warner, R. High pH in beef longissimus thoracis reduces muscle fibre transverse shrinkage and light scattering which contributes to the dark colour. Food Res. Int. 2017, 101, 228-238. [CrossRef] [PubMed]

71. Yu, Q.; Wu, W.; Tian, X.; Jia, F.; Xu, L.; Dai, R.; Li, X. Comparative proteomics to reveal muscle-specific beef color stability of Holstein cattle during post-mortem storage. Food Chem. 2017, 229, 769-778. [CrossRef] [PubMed]

72. Zhang, Y.M.; Zhang, X.Z.; Wang, T.T.; Hopkins, D.L.; Mao, Y.W.; Liang, R.R.; Yang, G.F.; Luo, X.; Zhu, L.X. Implications of step-chilling on meat color investigated using proteome analysis of the sarcoplasmic protein fraction of beef Longissimus lumborum muscle. J. Integr. Agric. 2018, 17, 2118-2125. [CrossRef]

73. Mahmood, S.; Turchinsky, N.; Paradis, F.; Dixon, W.T.; Bruce, H.L. Proteomics of dark cutting Longissimus thoracis muscle from heifer and steer carcasses. Meat Sci. 2018, 137, 47-57. [CrossRef]

74. Gagaoua, M.; Terlouw, E.M.C.; Picard, B. The study of protein biomarkers to understand the biochemical processes underlying beef color development in young bulls. Meat Sci. 2017, 134, 18-27. [CrossRef] [PubMed]

75. Purslow, P.P.; Warner, R.D.; Clarke, F.M.; Hughes, J.M. Variations in meat colour due to factors other than myoglobin chemistry; a synthesis of recent findings (invited review). Meat Sci. 2020, 159, 107941. [CrossRef] [PubMed]

76. Hughes, J.; Oiseth, S.K.; Purslow, P.P.; Warner, R.D. A structural approach to understanding the interactions between colour, water-holding capacity and tenderness. Meat Sci. 2014, 98, 520-532. [CrossRef] [PubMed]

77. Purslow, P.P.; Gagaoua, M.; Warner, R.D. Insights on meat quality from combining traditional studies and proteomics. Meat Science. 2021, 174, 108423. [CrossRef] [PubMed] 